\title{
Future evolution of aerosols and implications for climate change in the Euro-Mediterranean region using the CNRM-ALADIN63 regional climate model
}

\author{
Thomas Drugé, Pierre Nabat, Marc Mallet, and Samuel Somot \\ CNRM, Université de Toulouse, Météo-France, CNRS, Toulouse, France \\ Correspondence: Thomas Drugé (thomas.druge@ meteo.fr) \\ Received: 14 October 2020 - Discussion started: 8 December 2020 \\ Revised: 15 March 2021 - Accepted: 13 April 2021 - Published: 20 May 2021
}

\begin{abstract}
This study investigates, through regional climate modelling, the surface mass concentration and AOD (aerosol optical depth) evolution of the various (anthropogenic and natural) aerosols over the Euro-Mediterranean region between the end of the 20th century and the mid-21st century. The direct aerosol radiative forcing (DRF) as well as the future Euro-Mediterranean climate sensitivity to aerosols have also been analysed. Different regional climate simulations were carried out with the CNRM-ALADIN63 regional climate model, driven by the global CNRM-ESM2-1 Earth system model (used in CMIP6) and coupled to the TACTIC (Tropospheric Aerosols for ClimaTe In CNRM) interactive aerosol scheme. These simulations follow several future scenarios called shared socioeconomic pathways (SSP 1-1.9, SSP 3-7.0 and SSP 5-8.5), which have been chosen to analyse a wide range of possible future scenarios in terms of aerosol or particle precursor emissions. Between the historical and the future period, results show a total AOD decrease between $30 \%$ and $40 \%$ over Europe for the three scenarios, mainly due to the sulfate AOD decrease (between -85 and $-93 \%$ ), that is partly offset by the nitrate and ammonium particles AOD increase (between +90 and $+120 \%$ ). According to these three scenarios, nitrate aerosols become the largest contributor to the total AOD during the future period over Europe, with a contribution between $43.5 \%$ and $47.5 \%$. It is important to note that one of the precursors of nitrate and ammonium aerosols, nitric acid, has been implemented in the model as a constant climatology over time. Concerning natural aerosols, their contribution to the total AOD increases slightly between the two periods. The different evolution of aerosols therefore impacts their DRF, with a significant sulfate DRF decrease between 2.4 and $2.8 \mathrm{~W} \mathrm{~m}^{-2}$
\end{abstract}

and a moderate nitrate and ammonium DRF increase between 1.3 and $1.5 \mathrm{~W} \mathrm{~m}^{-2}$, depending on the three scenarios over Europe. These changes, which are similar under the different scenarios, explain about $65 \%$ of the annual shortwave radiation change but also about $6 \%$ (in annual average) of the warming expected over Europe by the middle of the century. This study shows, with SSP 5-8.5, that the extra warming attributable to the anthropogenic aerosol evolution over Central Europe and the Iberian Peninsula during the summer period is due to "aerosol-radiation" as well as "aerosol-cloud" interaction processes. The extra warming of about $0.2^{\circ} \mathrm{C}$ over Central Europe is explained by a surface radiation increase of $5.8 \mathrm{~W} \mathrm{~m}^{-2}$ over this region, due to both a surface aerosol DRF decrease of $4.4 \mathrm{~W} \mathrm{~m}^{-2}$ associated with a positive effective radiative forcing due to aerosol-radiation interactions (ERFari) of $2.7 \mathrm{~W} \mathrm{~m}^{-2}$ at the top of the atmosphere (TOA) and a cloud optical depth (COD) decrease of 1.3. In parallel, the simulated extra warming of $0.2^{\circ} \mathrm{C}$ observed over the Iberian Peninsula is due to a COD decrease of 1.3 , leading to a positive effective radiative forcing due to aerosol-cloud interactions (ERFaci) of $2.6 \mathrm{~W} \mathrm{~m}^{-2}$ at the TOA but also to an atmospheric dynamics change leading to a cloud cover decrease of about $1.7 \%$ and drier air in the lower layers, which is a signature of the semi-direct forcing. This study thus highlights the necessity of taking into account the evolution of aerosols in future regional climate simulations. 


\section{Introduction}

Due to their optical and microphysical properties, atmospheric aerosols are known to have an essential role in the regional and global climate system. Indeed, they are able to modify the entire energy balance as well as cloud properties and the hydrological cycle (Forster et al., 2007; Tang et al., 2018). The Earth's radiative budget is modified by aerosolradiation interactions (ari), which correspond to what is usually referred to as the direct and semi-direct aerosol effects, and also by aerosol-cloud interactions (aci) that include what has earlier been referred to as the indirect aerosol effect (Boucher et al., 2013). The direct radiative effect consists of the absorption and scattering of the incident radiation (Mitchell, 1971; Coakley et al., 1983). The absorption of solar radiation by aerosols can also affect the atmospheric thermodynamic properties and dynamics as well as the evaporation of clouds (semi-direct effect; Hansen et al., 1997; Allen and Sherwood, 2010). Finally, due to their role as condensation nuclei, aerosols can also modify the microphysical and radiative cloud properties, which notably have consequences on cloud albedo and lifetime (indirect effect; Twomey, 1977; Albrecht, 1989; Lohmann and Feichter, 2005). Over the past few years, efforts have been made to quantify the magnitude of the different aerosol radiative effects on the radiative budget (Boucher et al., 2013; Myhre et al., 2013a; Stevens, 2015; Allen et al., 2020) but their quantification still shows large uncertainties (Myhre et al., 2020; Bellouin et al., 2020).

The Mediterranean region is characterized by important aerosol loads composed of both natural (mineral dust and sea salt) and anthropogenic (sulfate, nitrate, ammonium, black and organic carbon) particles (Lelieveld et al., 2002; Nabat et al., 2013). These aerosols come from different sources such as the Sahara, but also from industries, European cities, forest fires and even the Mediterranean Sea itself (Lelieveld et al., 2002). This important variety in aerosol sources leads to complex physico-chemical and optical aerosol properties over the basin, making the Euro-Mediterranean region a particularly interesting area for studying aerosol-climate interactions (Basart et al., 2009; Nabat et al., 2015).

Besides, given the complex Euro-Mediterranean climate, which is highly dependant on orography and regional winds, the fluxes exchange between the Mediterranean Sea and the atmosphere, the significant contrasts of the surface albedo and the high spatial and temporal variability of aerosols, regional climate models with relatively fine resolution are therefore essential to investigate the aerosol-climate interactions over this region (Gibelin and Déqué, 2003; Gao et al., 2006; Giorgi and Lionello, 2008; Herrmann et al., 2011). Until recently, few studies have addressed the aerosol impact on the Euro-Mediterranean climate using a regional climate model over a multi-year period. Nevertheless, some studies have shown that aerosols have a strong impact on surface radiation, temperature and precipitation in this region (Zubler et al., 2011; Zanis et al., 2012; Spyrou et al., 2013; Nabat et al., 2015; Da Silva et al., 2018; Boé et al., 2020; Pavlidis et al., 2020). Indeed, Nabat et al. (2015) showed, thanks to the CNRM Regional Climate System Model (RCSM) oceanatmosphere coupled regional modelling system, which integrated a realistic aerosol climatology over the period 20032009 (Nabat et al., 2013), a surface shortwave direct aerosol radiative forcing (DRF) on the order of $-20 \mathrm{~W} \mathrm{~m}^{-2}$ over the Mediterranean Sea and North Africa and on the order of $-15 \mathrm{~W} \mathrm{~m}^{-2}$ over Europe. Other studies, such as Papadimas et al. (2012), have shown similar values over the Mediterranean basin with a mean aerosol DRF at the surface of about $-16.5 \mathrm{~W} \mathrm{~m}^{-2}$. Over Europe and the Mediterranean Sea, the cooling effect shown by Nabat et al. (2015) at the surface is partially offset by the semi-direct radiative effect, a consequence of a change in cloud cover and atmospheric circulation. At the surface, the net radiative forcing (direct + semi-direct aerosol effect) is therefore negative over Europe, the Mediterranean Sea and North Africa $(-16.2,-11.7$ and $-21.0 \mathrm{~W} \mathrm{~m}^{-2}$ respectively) and consequently leads to a surface cooling of about $0.5^{\circ} \mathrm{C}$ over the Mediterranean basin. Using a RegCM3 simulation, Zanis et al. (2012) showed in their study that the anthropogenic aerosols induced small changes in the yearly averaged surface temperature over Europe during the period 1996-2007 with a maximum temperature drop in the order of $0.2^{\circ} \mathrm{C}$ over the Balkan Peninsula. Finally, the study of Pavlidis et al. (2020) carried out over the period 2004-2008 with the Weather Research and Forecasting (WRF) model shows a negative direct aerosol effect over Europe ranging from -17 to $-5 \mathrm{~W} \mathrm{~m}^{-2}$ depending on the season, which is partly offset by small positive changes in the cloud radiative effect $\left(+5 \mathrm{~W} \mathrm{~m}^{-2}\right)$, attributed to the semi-direct aerosol effect. The authors of this study also showed that the study of aerosol-cloud interactions can lead to small changes in cloudiness, especially low-level clouds, and circulation anomalies in the lower and mid-troposphere. Lastly, they also highlighted a surface cooling between 0.1 and $0.5^{\circ} \mathrm{C}$ due to aerosol-radiation interactions. At the top of the atmosphere (TOA), the direct aerosol radiative forcing is more contrasted, with values that can be positive over North Africa (especially in summer) and negative over the Mediterranean Sea and Europe due to surface albedo differences (Nabat et al., 2015). Over a longer period of time, Nabat et al. (2014) have also shown the important role of aerosols in the climate trends observed in recent decades. In particular, they have shown that the sulfate aerosol decrease since the 1980s over Europe and the Mediterranean Sea has largely contributed to the incident solar radiation increase at the surface $(81 \pm 16 \%)$ as well as to the warming $(23 \pm 5 \%)$ over the Mediterranean region. This phenomenon has also been studied over Europe by Zubler et al. (2011) with the COSMO-CLM version over the period 1970-2000. In particular, they showed a strong brightening of up to $10 \mathrm{~W} \mathrm{~m}^{-2}$ in the annual mean over this period for mid-Europe.

The climate of the Mediterranean region, alternating between hot and dry summers and mild and wet winters, 
is highly reactive to current global climate change. The Mediterranean area is even considered as a climate change "hotspot" (Giorgi, 2006). Indeed, Jacob et al. (2014) have showed, based on a set of seven high-resolution regional models from the CORDEX project, a strong temperature increase at the end of the century (2071-2100) compared to the period $1971-2000$ that is on the order of 1 to $4.5^{\circ} \mathrm{C}$ with the representative concentration pathway (RCP) 4.5 and on the order of 2.5 to $5.5^{\circ} \mathrm{C}$ with the RCP 8.5. Other studies from the ENSEMBLES project have also predicted a temperature increase of the same order of magnitude with the A1B scenario (Hewitt, 2004; van der Linden and Mitchell, 2009). These various studies have also shown a significant precipitation increase of at least $25 \%$ over a large part of Central and northern Europe, as well as a precipitation decrease around the Mediterranean Sea. Other studies such as those of Giorgi and Lionello (2008) or of Thiébault and Moatti (2016) confirm these results. Given this Mediterranean climate sensitivity to climate change, but also the important aerosol radiative effect on the past and present climate of this region mentioned above, it is necessary to take into account the aerosol evolution to study the impact of these particles on the future Euro-Mediterranean climate. Boé et al. (2020) and Gutiérrez et al. (2020) have also recently highlighted the need to take into account the anthropogenic aerosol evolution in order to study the future evolution of climate over Europe and in particular the solar radiation changes. For the time being, a few studies have only addressed the variability of the surface fine particles mass concentration, in particular the $\mathrm{PM}_{10}$ and $\mathrm{PM}_{2.5}$, using air quality prediction models. These studies have shown a decline in $\mathrm{PM}_{10}$ over Europe in the future (Lacressonnière et al., 2014; Markakis et al., 2014; Lacressonnière et al., 2017; Cholakian et al., 2019). The intensity of this decrease depends on the period that is taken into account and on the inputs used. Cholakian et al. (2019) showed in particular a $\mathrm{PM}_{10}$ concentration decrease, in the 2050s, of about $12 \%$ over Europe for the RCP 4.5 .

Nevertheless, there are still few studies dedicated to investigating the impact of anthropogenic and natural aerosols on the future Euro-Mediterranean climate. Moreover, to our knowledge, this question has never been addressed by using a regional climate model with interactive aerosols providing a realistic description of the different particles and allowing for the study of their impact on the climate. In that context, the first aim of this study is to investigate the evolution of the different (natural and anthropogenic) aerosol loads (mass surface concentration and aerosol optical depth) in the future using the CNRM-ALADIN63 regional climate model and its TACTIC aerosol scheme (Nabat et al., 2020). In addition, the use of the recent anthropogenic emission dataset provided for the sixth phase of the Coupled Model Intercomparison Project (CMIP6) allows for more realistic emissions than those of previous studies. In addition, this regional modelling tool will serve to address the evolution of direct radiative forcing and the impact of aerosol evolu- tion on the future Euro-Mediterranean climate change. Since the CNRM-ALADIN63 regional climate model is uncoupled with the ocean, this study is mainly focused on quick climate responses to aerosols. After a description of the CNRMALADIN63 regional model and its aerosol scheme in Sect. 2, the evolution of the different aerosols as well as their radiative forcing will be presented in Sect. 3. The future EuroMediterranean climate sensitivity to aerosols will be discussed in Sect. 4 before the concluding remarks in Sect. 5 .

\section{Model and experiments}

\subsection{The CNRM-ALADIN63 regional climate model}

The current work has been carried out with the CNRMALADIN63 regional climate model (Nabat et al., 2020) that was developed at the CNRM (National Centre for Meteorological Research). It includes an interactive aerosol scheme described below. It also includes the SURFEX land surface module (Masson et al., 2013) with the ISBA scheme (Noilhan and Planton, 1989) that models water and energy exchanges at the interface between the plant, soil and atmosphere. SURFEX will then provide the mean values of different data such as the ascending radiation or the surface albedo, which are necessary for the CNRM-ALADIN63 model radiative scheme. Lastly, land surface hydrology and river flow are simulated by the TRIP model (Oki and Sud, 1998) according to the evaporation-precipitation balance provided by ISBA.

CNRM-ALADIN63 is a bi-spectral, hydrostatic limitedarea regional climate model with a semi-Lagrangian advection and a semi-implicit scheme. The configuration of CNRM-ALADIN63 used here over the Euro-Mediterranean region has a $50 \mathrm{~km}$ horizontal resolution and 91 vertical levels. Contrary to the globe, the domain is not periodic, so an extension zone used only for Fourier transforms has been added with the aim of achieving the bi-periodization. The CNRM-ALADIN63 model includes the Fouquart and Morcrette shortwave radiation scheme (FMR; Fouquart and Bonnel, 1980; Morcrette et al., 2008) with six spectral bands and the RRTM (rapid radiative transfer model) longwave radiation scheme (Mlawer et al., 1997).

The Euro-Mediterranean domain chosen for this study, presented in Fig. 1, includes the official domain of the MedCORDEX initiative (Ruti et al., 2016) as well as an extension to take into account the two main dust sources (the Sahara and the largest part of the Arabian Peninsula). This domain represents $128 \times 180$ points, including a bi-periodization of 11 points (north and east) and a classical relaxation zone of 8 points (on each side). The Europe and the Mediterranean Sea regions are highlighted in Fig. 1 for the needs of this study. 


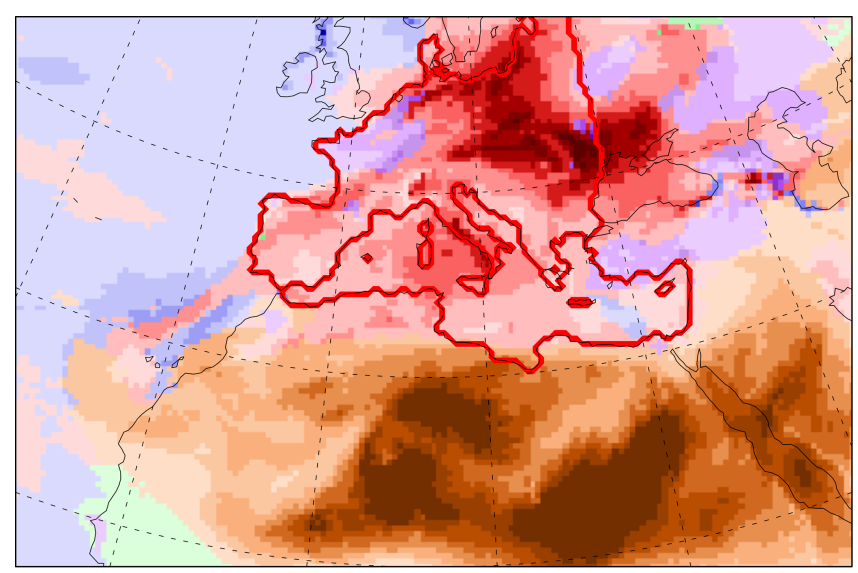

SALT AMMO ORGA NITR SULF BLCA DUST

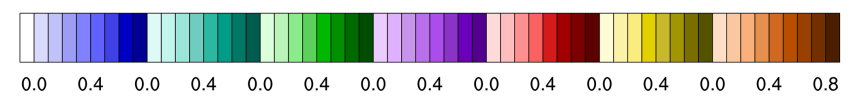

Figure 1. AOD of the dominant aerosol species (sea salt, ammonium, organic carbon, nitrate, sulfate, black carbon and dust) at each point over the Euro-Mediterranean region (28 August 1974). The inner model domain, without the bi-periodization and the relaxation zones, represents $101 \times 153$ points. The projection type used here is the Lambert conformal projection. The two main zones used in this study, Europe and the Mediterranean Sea, are highlighted in red.

\subsection{The TACTIC aerosol scheme}

CNRM-ALADIN63 incorporates an interactive aerosol scheme named TACTIC (Tropospheric Aerosols for ClimaTe In CNRM; Michou et al., 2015; Nabat et al., 2015; Watson et al., 2018; Drugé et al., 2019; Michou et al., 2020; Nabat et al., 2020), which was originally based upon the GEMS/MACC aerosol module of the ECMWF operational forecast model (Morcrette et al., 2009). The version of this aerosol scheme used in this study is described in detail in Nabat et al. (2020).

Initially, this aerosol scheme takes into account five aerosol types (desert dust, sea salt, black carbon, organic matter and sulfate) and recently nitrate and ammonium particles have been added as presented in Drugé et al. (2019). The TACTIC aerosol scheme makes it possible to simulate the aerosol life cycle (emission, transport and deposition), considering the different aerosols as prognostic variables and taking into account their direct and semi-direct radiative effects. The first indirect aerosol effect (cloud albedo) is also represented for sulfate, organic matter and sea salt aerosols. On the other hand, the second indirect effect (interactions between aerosols and cloud microphysics) is not included in this aerosol scheme. Finally, secondary organic aerosols (SOAs) are taken into account through the climatology of Dentener et al. (2006), but their formation is not explicitly included in the TACTIC aerosol scheme.
To represent the particle size spectrum, the TACTIC aerosol scheme includes 16 prognostic variables using several size bins for some specific species. In detail, three size bins are used for dust aerosols ( 0.01 to $1.0,1.0$ to 2.5 and 2.5 to $20 \mathrm{~m})$ and for primary sea salt $(0.01$ to $1.0,1.0$ to 10.0 and 10.0 to $100.0 \mathrm{~m}$ ). Organic matter and black carbon aerosols are both separated into two different bins (hydrophilic and hydrophobic particles). Only one bin is used for sulfate particles and another is used for its precursors, notably sulfur dioxide $\left(\mathrm{SO}_{2}\right)$. Recently, nitrate aerosols have been included in the TACTIC aerosol scheme (Drugé et al., 2019). This specific tracer is divided into two different bins (for fine and coarse modes). The last two bins are used for ammonium and ammonia tracers. It is important to note that one of the ammonium and nitrate aerosol precursors, nitric acid $\mathrm{HNO}_{3}$, is implemented in the model as a constant monthly climatology based on the CAMS reanalysis (Inness et al., 2019), which is an important limitation in this study. Nevertheless, a sensitivity test (not shown here) highlighted that in the CNRM-ALADIN63 model, the nitrate concentration is impacted relatively little by the use of a constant or timedependent nitric acid climatology. This constant $\mathrm{HNO}_{3}$ climatology used in this model version for past and future simulations, and the whole nitrate-ammonium module, are described in detail in Drugé et al. (2019). The different primary aerosol mass concentrations can be dynamically calculated online as a function of surface wind and soil characteristics (dust, primary sea salt) or based on external emission datasets from anthropogenic and/or biomass burning particles (black carbon, organic matter, sulfate, nitrate and ammonium). After being emitted into the atmosphere, all aerosol species are then transported and submitted to the dry and wet (in and below clouds) deposition. Finally, it is important to note that in the present study, the defined ALADIN domain is supposed to be large enough to include all aerosol sources affecting the Euro-Mediterranean region and the long-range transport of particles is not included in the lateral boundary forcing.

The different radiative properties of each aerosol species, and notably those used as input for the radiative transfer scheme (the extinction coefficient, asymmetry parameter and single scattering albedo), are set for each aerosol type following Nabat et al. (2013) and Drugé et al. (2019). These different aerosol optical properties are pre-calculated using a Mie code using the hypothesis of aerosol sphericity (Ackerman and Toon, 1981) and are dependant on relative humidity, with the exception of mineral dust and hydrophobic black and organic carbon particles.

The different simplifications presented previously, such as the limited number of bins used for anthropogenic aerosols, the hypothesis of the external mixing state between the different species or the fact that the aerosol optical properties are not calculated online in the model, are necessary to keep the regional model at a reasonable computation cost, which in this configuration is well adapted to perform multi-decadal simulations. 

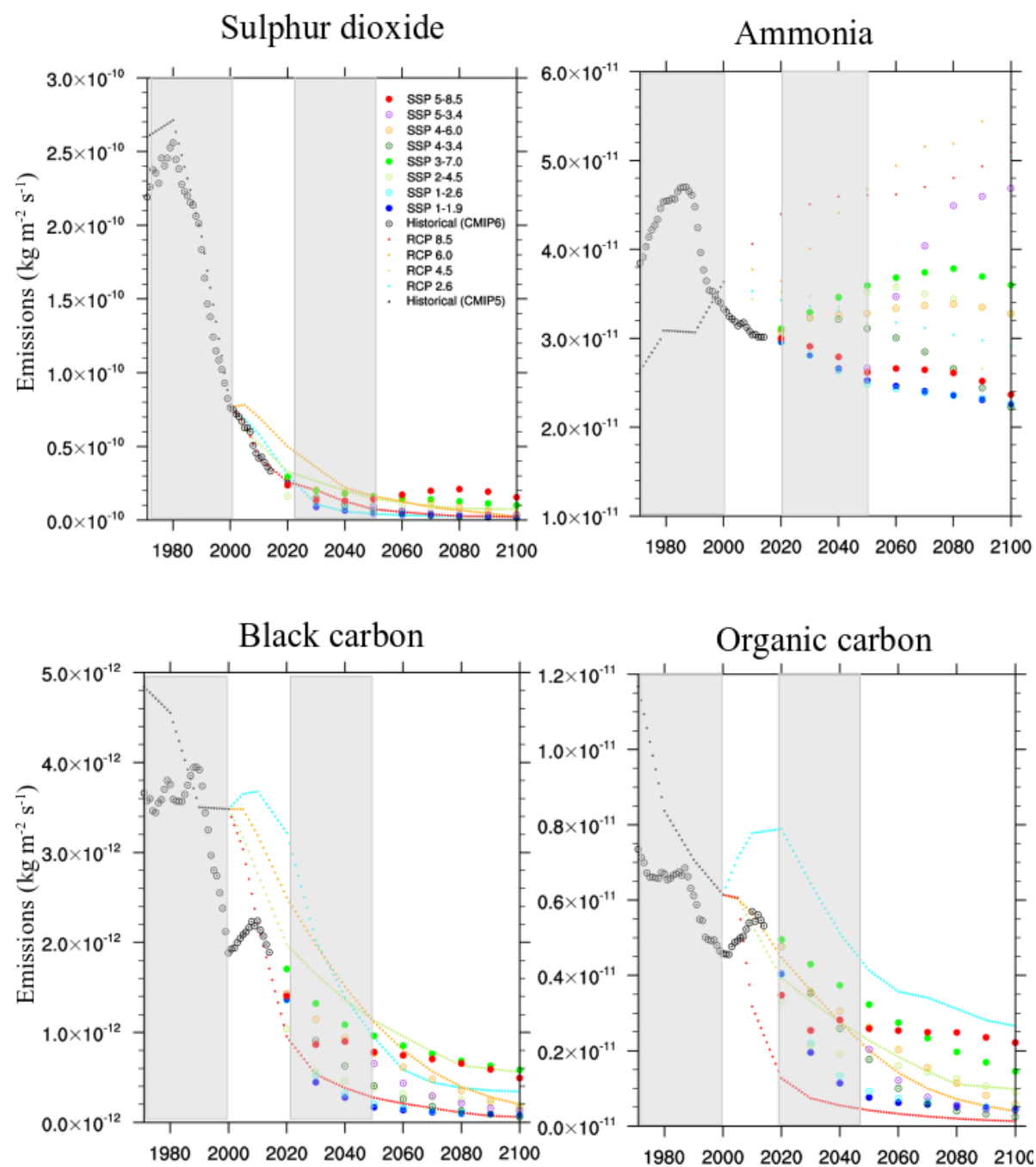

Figure 2. CMIP5 and CMIP6 emissions $\left(\mathrm{kg} \mathrm{m}^{-2} \mathrm{~s}^{-1}\right)$ over Europe from the main activity sectors (residential, agriculture, energy, industrial, air, land and sea transport, waste and solvents) for sulfur dioxide, ammonia, black carbon and organic carbon. The large filled dots symbolize the three scenarios chosen for this study (SSP 1-1.9, SSP 3-7.0 and SSP 5-8.5). Shaded bars highlight the past and future simulations period.

\subsection{Simulations}

The TACTIC aerosol scheme presented previously allows us to study in the following section the variation of aerosols between the past (from 1971 to 2000; reference period commonly used) and the future (from 2021 to 2050) period. The near future has been selected as the future period because, unlike greenhouse gases, the most important aerosol change is up to the middle of the century (see Figs. 2 and 3). In their study, Allen et al. (2020) have effectively shown that non-methane mitigation leads to a net warming effect in the near-term due to the removal of aerosol. Moreover, the near future horizon period is most suitable to help public decision-makers. For this purpose, a first simulation over the past period (1971-2000) and three simulations over the future period (2021-2050) were carried out. These future ALADIN simulations are based on three shared socioeco- nomic pathways (SSPs; O'Neill et al., 2017), namely SSP 11.9, SSP 3-7.0 and SSP 5-8.5. The choice of these scenarios will be explained below (Sect. 3.1). These four simulations will be named Hist, SSP119, SSP370 and SSP585 respectively. All these different simulations use the CMIP6 dataset for the emission of the different aerosols or aerosol precursors. The historical dataset is based on two main sources, namely the anthropogenic emissions (Hoesly et al., 2018) and the biomass burning emissions (van Marle et al., 2017). The anthropogenic emissions of the different aerosols and their precursors are provided from the main sectors of activity (residential, agriculture, energy, industrial, air, land and sea transport, waste and solvents) for each country and for each grid point at $0.5^{\circ}$ resolution, while the emissions from biomass fires (natural and anthropogenic) are provided over the period 1750-2014. Future CMIP6 emissions are provided 


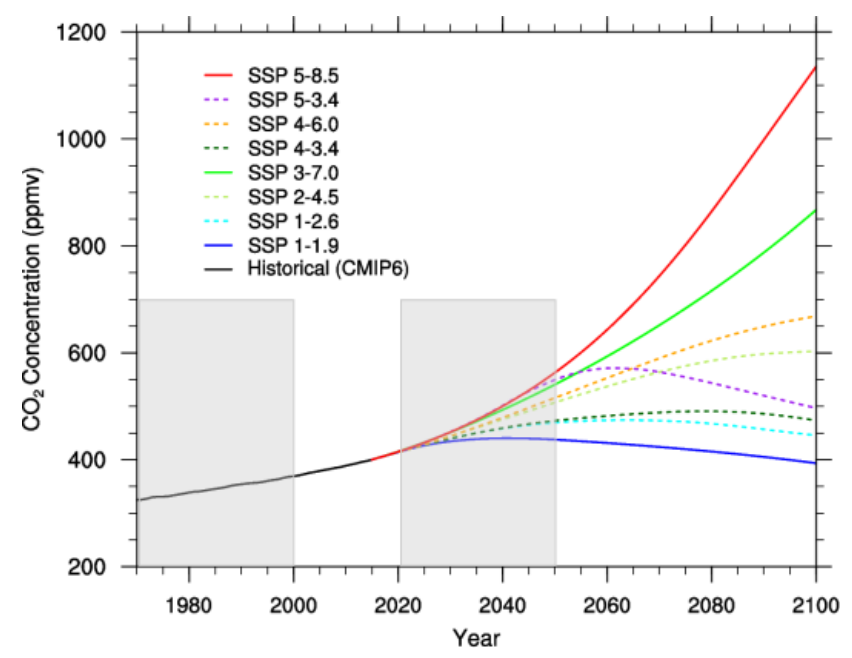

Figure 3. Global $\mathrm{CO}_{2}$ concentration evolution (ppmv) over the period 1970-2100 according to eight different SSPs. The three scenarios chosen for this study (SSP 1-1.9, SSP 3-7.0 and SSP 5-8.5) are highlighted by solid lines. Shaded bars highlight the past and future simulations period.

in the same format, derived from the different SSPs (Gidden et al., 2019).

Finally, a fifth simulation named SSP585cst, which will be used in Sect. 4 of this study was also carried out with the SSP 5-8.5. This simulation is similar to the SSP585 simulation but with constant aerosol and aerosol precursor emissions that correspond to the average historical emissions over the 1971-2000 period. As a reminder, these five simulations were carried out at $50 \mathrm{~km}$ resolution with the CNRMALADIN63 model including the TACTIC aerosol scheme and are uncoupled with the ocean. No specific spinup was used for these simulations but the restart is that of the end of the simulations presented in Drugé et al. (2019). Atmospheric lateral boundary conditions, sea surface temperature, sea ice cover and ozone concentrations come from historical and respective scenario simulations carried out with the global Earth system model CNRM-ESM2-1 (Séférian et al., 2019) presented below. As the chosen domain is assumed to be large enough to include the main sources of aerosols over the Euro-Mediterranean region, no aerosols are transmitted from the global model CNRM-ESM2-1 to the regional model CNRM-ALADIN63. Land use changes are not considered in this study. The historical evolution of the different greenhouse gases (GHGs) is included in these simulations following the yearly global averages of Meinshausen et al. (2017). Besides, following Matthes et al. (2017), the total solar irradiance forcing is also taken into account with yearly averages. Finally, the stratospheric aerosol radiative forcing, including the contribution of the main historical volcanic eruptions such as Mt. Pinatubo in 1991, is included through the Thomason et al. (2018) dataset, providing stratospheric AOD at $550 \mathrm{~nm}$. Table 1 summarizes the characteristics of the different simulations used in this study.

All these simulations are driven by the CNRM-ESM21 Earth system model (Séférian et al., 2019), which has a horizontal resolution of about $150 \mathrm{~km}$. This global climate model, which contributes to the sixth phase of the Coupled Model Intercomparison Project (CMIP6; Eyring et al., 2016), is developed by the CNRM and CERFACS (European Center for Research and Advanced Training in Scientific Computing) modelling groups. The physical core of this climate model is the global coupled ocean-atmosphere model CNRM-CM, whose version 6 is used here (Voldoire et al., 2019). CNRM-ESM2-1 is mainly dedicated to the realization of climate scenarios and is composed of different models such as the ARPEGE climate model (Roehrig et al., 2020) for the atmosphere, NEMO for the ocean (Madec et al., 2017) and REPROBUS (Lefevre et al., 1994) for the chemistry. Like the CNRM-ALADIN63 model, this global model also includes the TACTIC prognostic aerosol scheme, including all the aerosols present in TACTIC with the exception of nitrate and ammonium particles. The CNRM-ESM21 model also integrates the SURFEX continental surface modelling platform (Masson et al., 2013) with the ISBACTRIP land surface model (Decharme et al., 2019) and a lake model named Flake (http://www.flake.igb-berlin.de/, last access: 17 May 2021; Le Moigne et al., 2016). Finally, the CNRM-ESM2-1 model also integrates a sea ice scheme (GELATO; Mélia, 2002) and a marine biogeochemistry module (PISCES; Aumont and Bopp, 2006). All these CNRM-ESM2-1 model components are presented in detail in Séférian et al. (2019). It is worth mentioning that CNRMALADIN63 and CNRM-ESM2-1 share the same physical basis (atmosphere, surface, aerosols) and the same climate forcings (solar forcing, GHGs, aerosol emissions, ozone) as much as possible.

\subsection{Anthropogenic CMIP6 emissions}

As mentioned above, the CMIP6 emissions of aerosols or aerosol precursors are provided by Hoesly et al. (2018) and van Marle et al. (2017) for the historical period (1750-2014) and by Gidden et al. (2019) for the future period (2015$2100)$ following the various SSPs. The anthropogenic emissions, ranging from 1971 to 2100 over Europe, are presented in Fig. 2 for sulfur dioxide, ammonia, black carbon and organic carbon according to the different existing scenarios. Compared to the previous CMIP5 inventory, which has been improved by taking better account of the different emission sectors as well as re-evaluated emission factors, this CMIP6 dataset presents some differences as shown in Fig. 2, in particular for ammonia emissions. Indeed, CMIP6 anthropogenic ammonia emissions show a decrease from the 1990s, whereas the previous CMIP5 inventory showed the opposite trend with an increase in ammonia emissions. Despite this, for other aerosols or aerosol precursors, trends are similar 
Table 1. Summary of the main characteristics of the five simulations used in this study.

\begin{tabular}{llllll}
\hline & Hist & SSP119 & SSP370 & SSP585 & SSP585cst \\
\hline Period of simulation & \multirow{2}{*}{$1971-2000$} & 2021-2050 & 2021-2050 & 2021-2050 & 2021-2050 \\
$\begin{array}{l}\text { Scenario } \\
\text { Anthropogenic aerosol emissions }\end{array}$ & \multirow{2}{*}{ Historical } & SSP 1-1.9 & SSP 3-7.0 & SSP 5-8.5 & SSP 5-8.5 \\
& & SSP 1-1.9 & SSP 3-7.0 & SSP5-8.5 & Historical (average) \\
\hline
\end{tabular}

between the two datasets, such as for sulfur dioxide, which shows a peak in the early 1980s followed by a significant decrease in both emission inventories. Figure 2 shows a decrease in emissions over the historical period for all aerosols, particularly from the 1990s. The most significant decrease, by about $80 \%$, concerns sulfur dioxide, a precursor of sulfate aerosols, which had the highest emissions. Indeed, sulfur dioxide emissions were approximately divided by five between 1980 and 2010. Concerning the different scenarios, this figure shows that, with the exception of ammonia, the majority of them predict a decrease in the different emissions in the future. However, in the ammonia case, several scenarios such as the SSP 5-3.4, the SSP 4-6.0 or the SSP 3-7.0 predict higher emissions by 2100 compared to $2010(+60 \%$, $+10 \%$ and $+20 \%$ respectively).

The choice of the three scenarios used in this study gives a contrasted range of values in terms of radiative forcing but also in terms of aerosol or aerosol precursor emissions. In addition, as shown in Fig. 3, which presents the $\mathrm{CO}_{2}$ concentration evolution, the SSPs 1-1.9 and 5-8.5 allow us to have the widest possible range of future radiative forcing. Lastly, the SSP 1-1.9 is interesting as it represents one of the few combinations that can be used to comply with the Paris Agreement and thus limit the global temperature increase to $1.5^{\circ} \mathrm{C}$ by 2100. The SSP 3-7.0 was chosen as an intermediate scenario between the SSP 1-1.9 and the SSP 5-8.5 and because it is one of the scenarios characterized by an ammonia emission increase. These different scenarios thus make it possible to study the evolution of all the aerosols present over the EuroMediterranean region thanks to a wide range of possible futures in terms of concentration and optical thickness of the different aerosols.

\section{Future evolution of aerosols and their radiative forcing}

\subsection{Surface mass concentration and AOD evolution}

The total AOD evolution between the past (1971-2000) and the future (2021-2050) periods can be seen in Fig. 4. In more detail, Fig. 5 presents the aerosol evolution between these two periods in terms of surface mass concentration and AOD for each aerosol type over both Europe (a) and the Mediterranean Sea (b). First of all, Fig. 5 indicates that the total aerosol surface mass concentration over the Mediterranean Sea is significantly higher than over Europe, in particular due to the large amount of natural aerosols such as desert dust or primary sea salts over this area. Nevertheless, over the period 1971-2000, the total AOD over Europe is similar to that over the Mediterranean Sea on the order of 0.2. Concerning the aerosol evolution between the historical period 1971-2000 and the future period 2021-2050, Figs. 4 and 5 show a future concentration and total AOD decrease over Europe and the Mediterranean Sea. Figure A1 shows that this AOD trend over Europe present in the CNRM-ALADIN63 model ( -0.07 on average) is also found with its forcing model (CNRM-ESM2-1; -0.08 on average) as well as with the average of the different members carried out with this ESM model ( -0.08 on average). In terms of AOD, Figs. 4 and 5 show an annual decrease equivalent to about -0.07 on average according to the SSP 5-8.5 over Europe and -0.02 over the Mediterranean Sea. This total AOD decrease is explained, in part, by the strong decrease in sulfate concentration and AOD that is notable between the past and the future periods in all months of the year. Indeed, over Europe, sulfate AOD decreases from 0.12 on average over the historical period to 0.01 over the future period according to the SSP 5-8.5, i.e. a decrease of $90 \%$. Similarly, over the Mediterranean Sea this decrease is on the order of $85 \%$. However, this sharp sulfate AOD drop and thus the total AOD decrease is compensated for by a nitrate and ammonium AOD increase of about $30 \%$, as shown in Fig. 5. On average over Europe (Fig. 5a), the nitrate AOD increases from 0.03 (0.01 for ammonium) over the period 1971-2000 to 0.06 (0.02 for ammonium) over the period 2021-2050, i.e. a $100 \%$ increase again according to the SSP 5-8.5. Over the Mediterranean Sea (Fig. 5b), the AOD of theses particles increases by about $300 \%$ for nitrate aerosols and about $230 \%$ for ammonium aerosols. Figure 5 also shows some smaller changes in dust and sea salt aerosols over the Mediterranean Sea, particularly in terms of concentration, between historical and future periods. Concerning the other aerosols (organic carbon and black carbon), they do not show strong concentration or AOD changes between the two periods studied either over Europe or over the Mediterranean Sea.

Finally, Fig. 4 also shows a total AOD increase over the western and eastern part of Africa according to the three scenarios studied. This increase is due both to a nitrate and ammonium AOD increase but also to an increase in dust AOD during the summer and in particular during the months of July and August over this region. This result is illustrated in Fig. 6, which shows the different aerosol evolution be- 
(a) - SSP 5-8.5

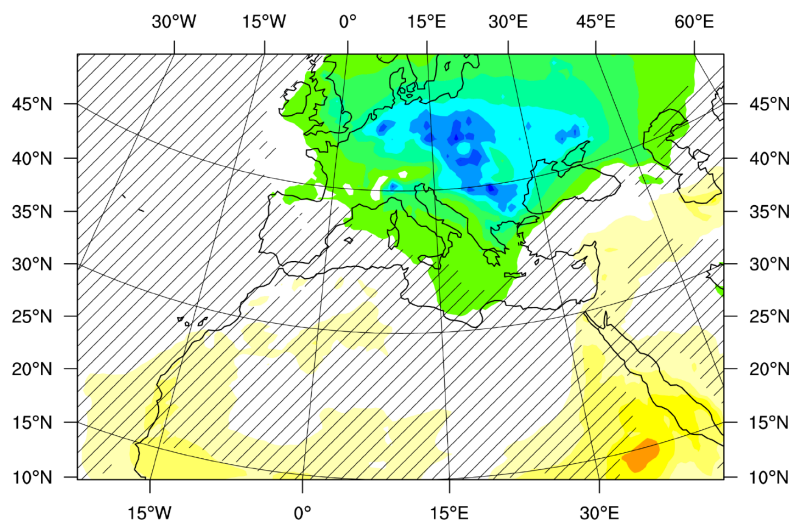

(b) - SSP 3-7.0

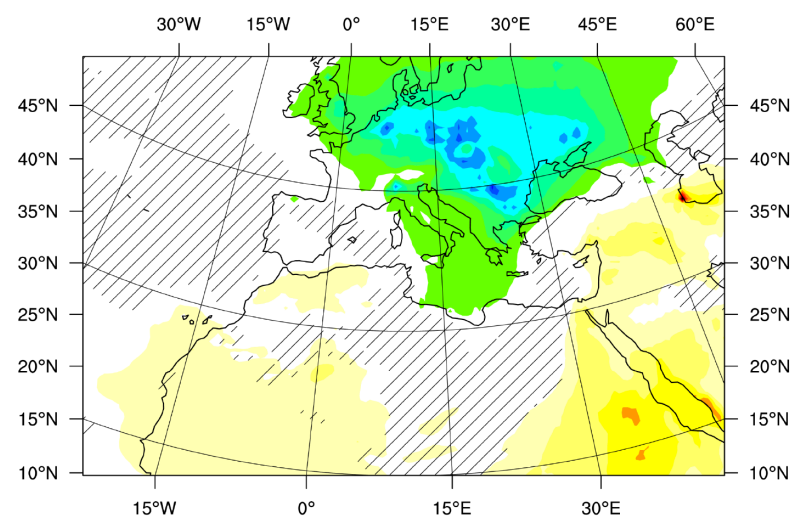

(c) - SSP 1-1.9

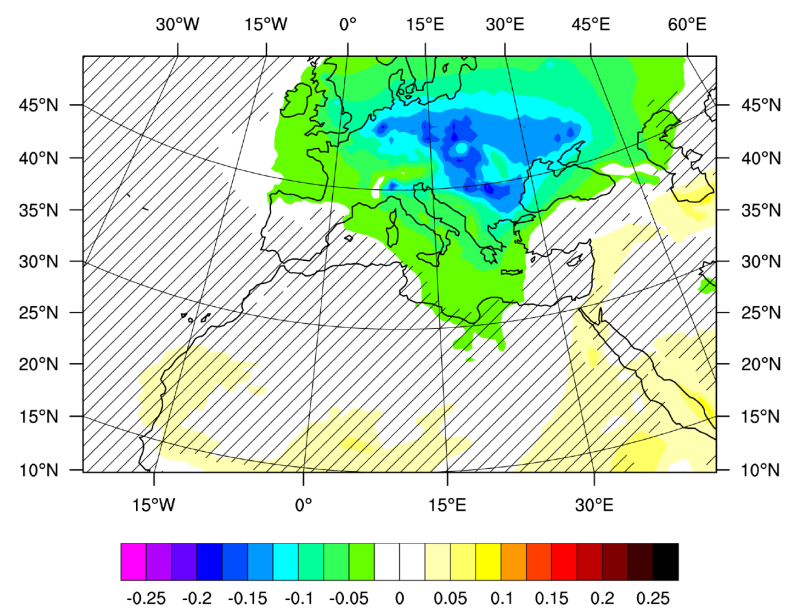

Figure 4. Total AOD evolution between the past period (19712000) and the future period (2021-2050) following SSP 5-8.5 (a), SSP 3-7.0 (b) and SSP 1-1.9 (c). The hatched areas are statically non-significant with a threshold of $10 \%$.

tween the period 1971-2000 and the period 2021-2050 for the SSP 5-8.5 over the East African region shown in black. The dust AOD increase during the summer between the two periods is due to a wind speed increase, shown in Fig. 7, and therefore higher dust emissions. In addition, Fig. 7 shows
Table 2. Relative contribution (\%) of the different aerosols to the total AOD (550 nm) over the historical period (1971-2000) and the future period (2021-2050) according to SSPs 1-1.9, 3-7.0 and 5-8.5.

\begin{tabular}{lrrrr}
\hline & Historical & SSP 1-1.9 & SSP 3-7.0 & SSP 5-8.5 \\
\hline Europe & & & & \\
\hline Sulfate & 60 & 7 & 13 & 10 \\
Nitrate & 15 & 47.5 & 43.5 & 46 \\
Ammonium & 5 & 17 & 14.5 & 15.5 \\
Organic carbon & 6 & 6 & 8 & 8 \\
Black carbon & 2 & 1 & 1.5 & 1.5 \\
Sea salt & 7 & 12 & 10.5 & 11 \\
Dust & 5 & 9.5 & 9 & 9 \\
\hline Mediterranean Sea & & & & \\
\hline Sulfate & 38.5 & 7 & 16 & 9 \\
Nitrate & 6 & 23 & 19 & 21.5 \\
Ammonium & 1.5 & 7.5 & 6 & 7 \\
Organic carbon & 4 & 3.5 & 5 & 4.5 \\
Black carbon & 1.5 & 1 & 2 & 1.5 \\
Sea salt & 14.5 & 17 & 15 & 16.5 \\
Dust & 34 & 41 & 37 & 40 \\
\hline
\end{tabular}

that the wind increase during the summer present in the CNRM-ALADIN63 model is also found with its forcing model (CNRM-ESM2-1) as well as with the average of the different members carried out with this global model. The nitrate and ammonium AOD increase over this region is due to an increase in ammonia emissions but also to an increase in dust emissions and therefore to more calcite available, which will then react with nitric acid to form nitrate and ammonium aerosols (Drugé et al., 2019).

The most important concentration and AOD changes between the past and the future period therefore occur over Europe and are mainly due to a strong sulfate concentration and AOD decrease, which is partly offset by the nitrate and ammonium concentration and AOD increase. Figures 4 and 5 show that these changes are robust to the three scenarios used in this study. Nevertheless, the SSP 3-7.0 shows the smallest total AOD decrease over Europe with a decline of 0.06, compared to 0.07 with the SSP 5-8.5 and 0.08 with the SSP 1-1.9. This is due to a more moderate sulfate AOD decrease and a slight nitrate AOD increase, initially due to higher sulfur dioxide and ammonia emissions with this scenario. Except for these few variations, all results showed a total AOD decrease over Europe for the three scenarios (SSP 1-1.9, SSP 3-7.0 and SSP 5-8.5). These results are therefore in agreement with the first studies that addressed the fine particles evolution, and in particular $\mathrm{PM}_{10}$ and $\mathrm{PM}_{2.5}$, which forecast a fine particles decrease over Europe by the end of the century (Markakis et al., 2014; Lacressonnière et al., 2017; Cholakian et al., 2019). These results are also consistent with Boé et al. (2020) and Gutiérrez et al. (2020) studies that predict a decline in total aerosol AOD by the middle of the century. 
(a) - Europe
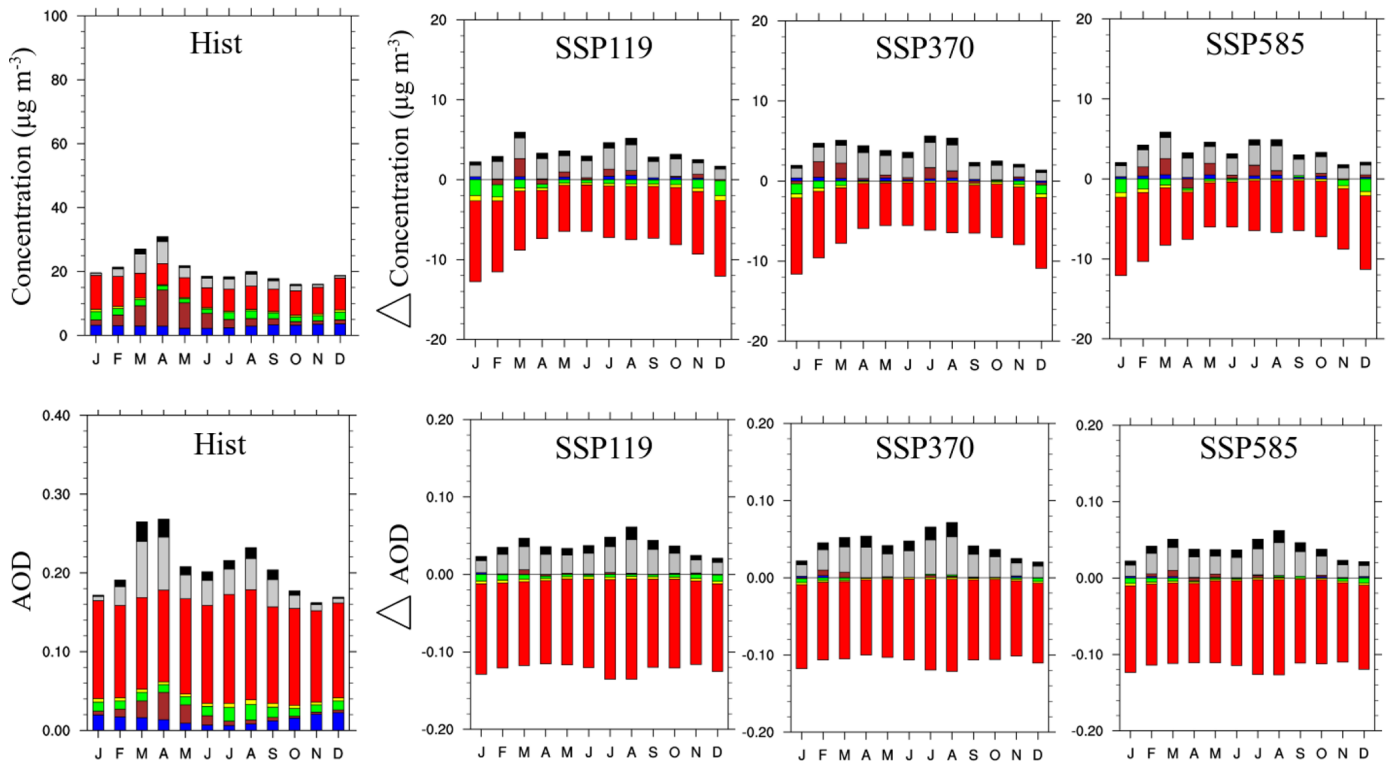

(b) - Mediterranean Sea
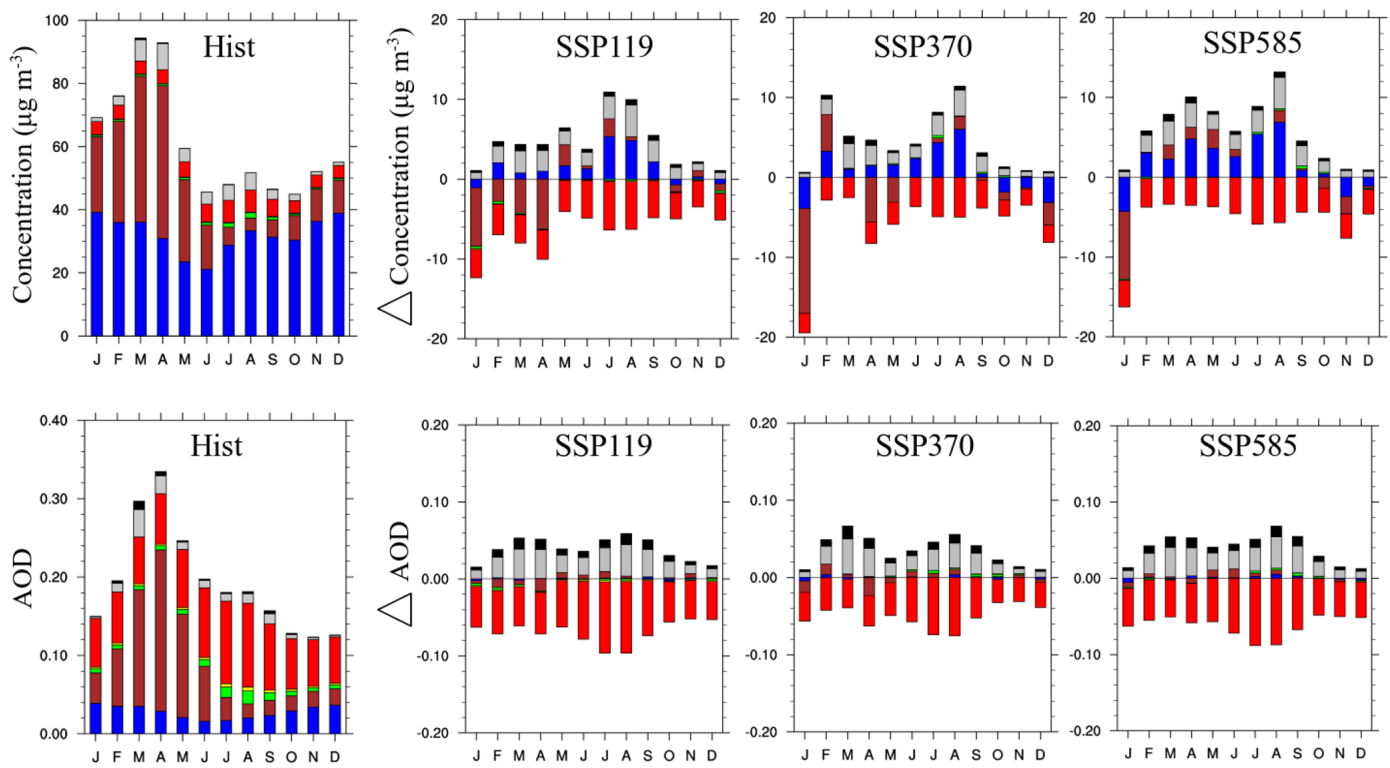

$\square$ Sea salt

Dust

Organic matter

Black carbon

Sulfate

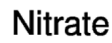

\section{Ammonium}

Figure 5. Surface concentration $\left(\mu \mathrm{g} \mathrm{m}^{-3}\right.$ ) and AOD evolution of the different aerosols between the past period (1971-2000) and the future period (2021-2050) according to SSP 1-1.9, SSP 3-7.0 and SSP 5-8.5 over Europe (a) and the Mediterranean Sea (b).

Following the evolution of these different aerosol types, their contribution to the total AOD will therefore also change between the past and the future periods. Table indicates the relative contribution of each aerosol type to the future total AOD (2021-2050) over Europe and the Mediterranean Sea under the three different scenarios. This table shows that nitrate particles are the highest contributor to the total AOD over Europe for the future period, with a contribution of about $45 \%$ over the period 2021-2050 according to the different SSPs compared to only $15 \%$ over the period 1971- 

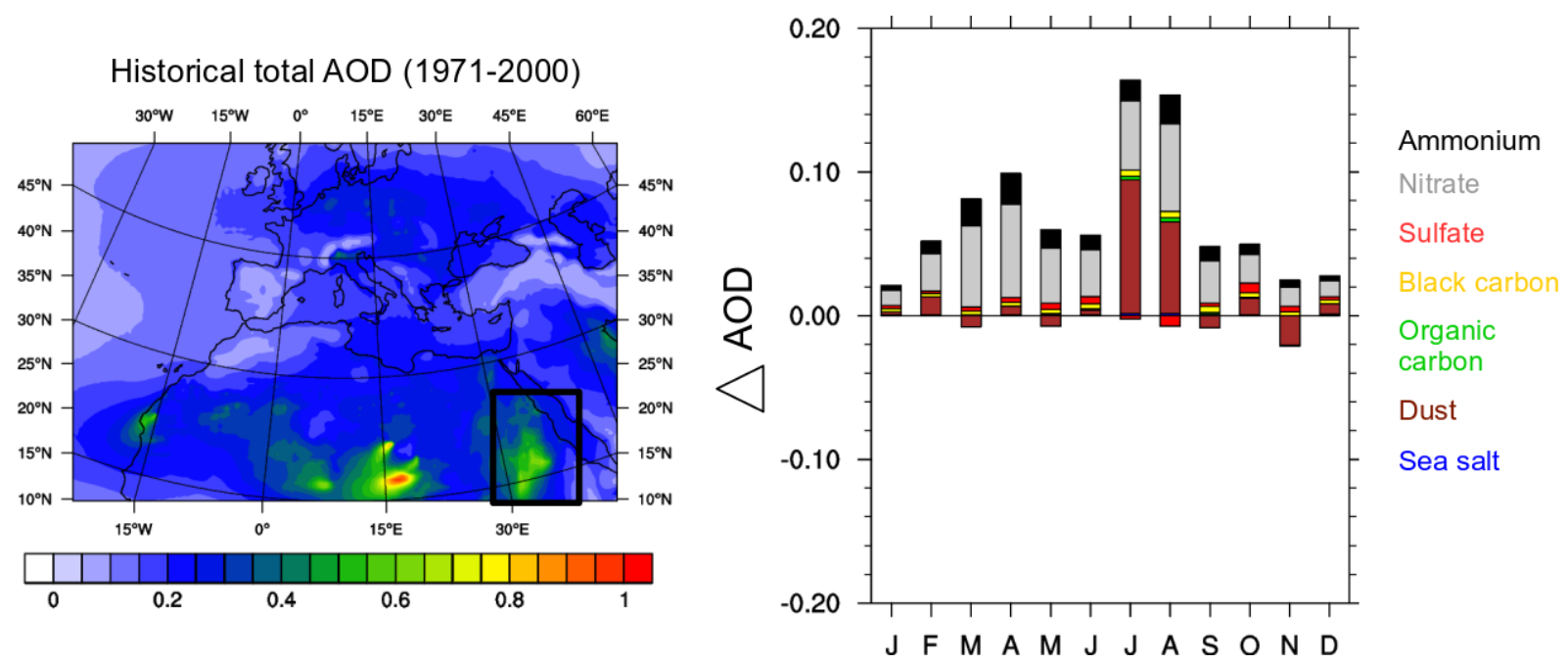

Figure 6. Historical total AOD and its evolution between the past period (1971-2000) and the future period (2021-2050) according to the SSP 5-8.5 over the East African region, which is framed in black. The hatched areas are statically non-significant with a threshold of $10 \%$.
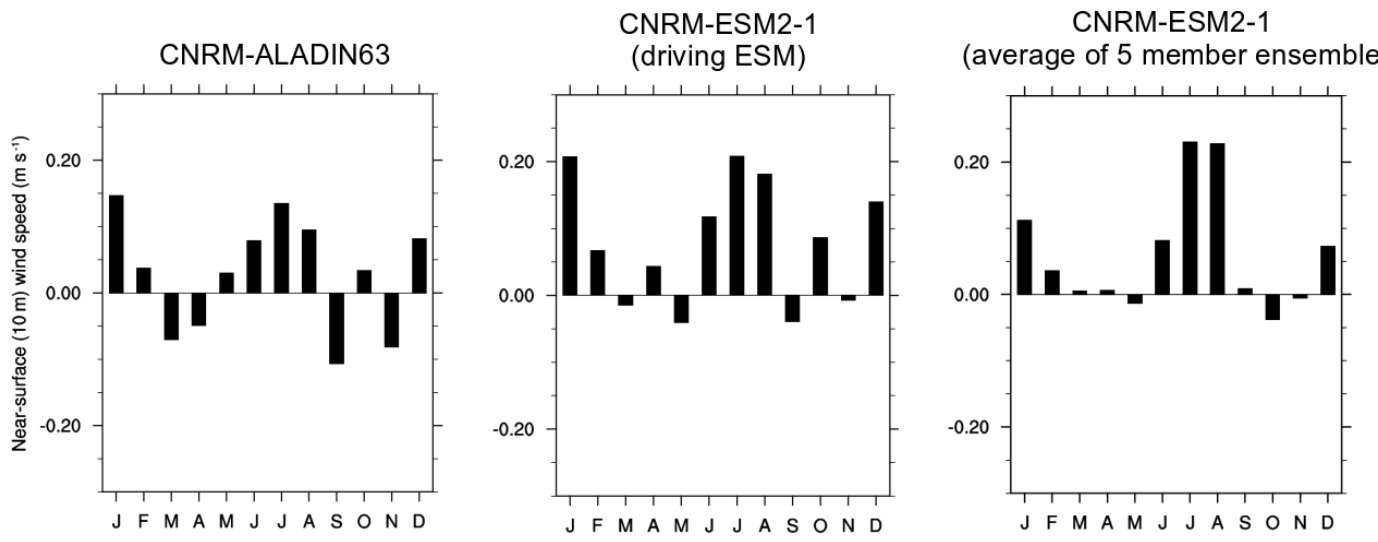

Figure 7. Near-surface wind speed evolution $\left(\mathrm{m} \mathrm{s}^{-1}\right)$ between the past period (1971-2000) and the future period (2021-2050) according to the SSP 5-8.5 over the East African region with the CNRM-ALADIN63 model and its driving ESM.

2000. The contribution of these aerosols to the total AOD is the highest $(47.5 \%)$ when using the SSP 1-1.9. These results are consistent with the Bellouin et al. (2011) and Drugé et al. (2019) studies, which show that nitrate particles are or would become the dominant aerosol species over Europe. In addition Drugé et al. (2019) show, over the period 1979-2016, that the ammonium and nitrate concentrations increase over Europe is due to the decrease in sulfate aerosol production, which produces more free ammonia in the atmosphere. At the global scale, Papadimas et al. (2012) also showed that nitrate particles will increase from a contribution of $23 \%$ to anthropogenic AOD (year 2000) to $56 \%$ (year 2090) for the RCP 4.5 scenario. Concerning the Mediterranean Sea, Table indicates a historical natural (sea salt and dust) aerosols contribution to the total AOD of about $50 \%$. These results are consistent with the study of Georgoulias et al. (2016) carried out over the eastern Mediterranean and based on MODIS
Aqua (2002-2012) and MODIS Terra (2000-2012) observations that show a dust and sea salt aerosols contribution to the total AOD $(550 \mathrm{~nm})$ of about $60 \%$. Over this region, Table shows that nitrate aerosols become the second highest contributor to the total AOD, of about $20 \%$ according to the three SSPs, just behind desert dust particles, which contribute of about $40 \%$ to the total AOD. In addition to nitrate particles, the ammonium aerosol contribution to the total AOD over Europe also shows a clear increase between the two periods by a factor of 3 , from $5 \%$ to $15 \%$. Conversely, sulfate particles, which are the highest contributors $(60 \%)$ to the total AOD during the period 1971-2000 over Europe would contribute only at $10 \%$ to the future total AOD with the SSP 5-8.5 (7\% with the SSP 1-1.9 and $13 \%$ with the SSP 3-7.0). Over the Mediterranean Sea, sulfate also shifts from the highest contributor (38.5\%) to one of the least contributing species to the total AOD except with the SSP 3- 


\section{SW Direct radiative forcing (1971-2000)}

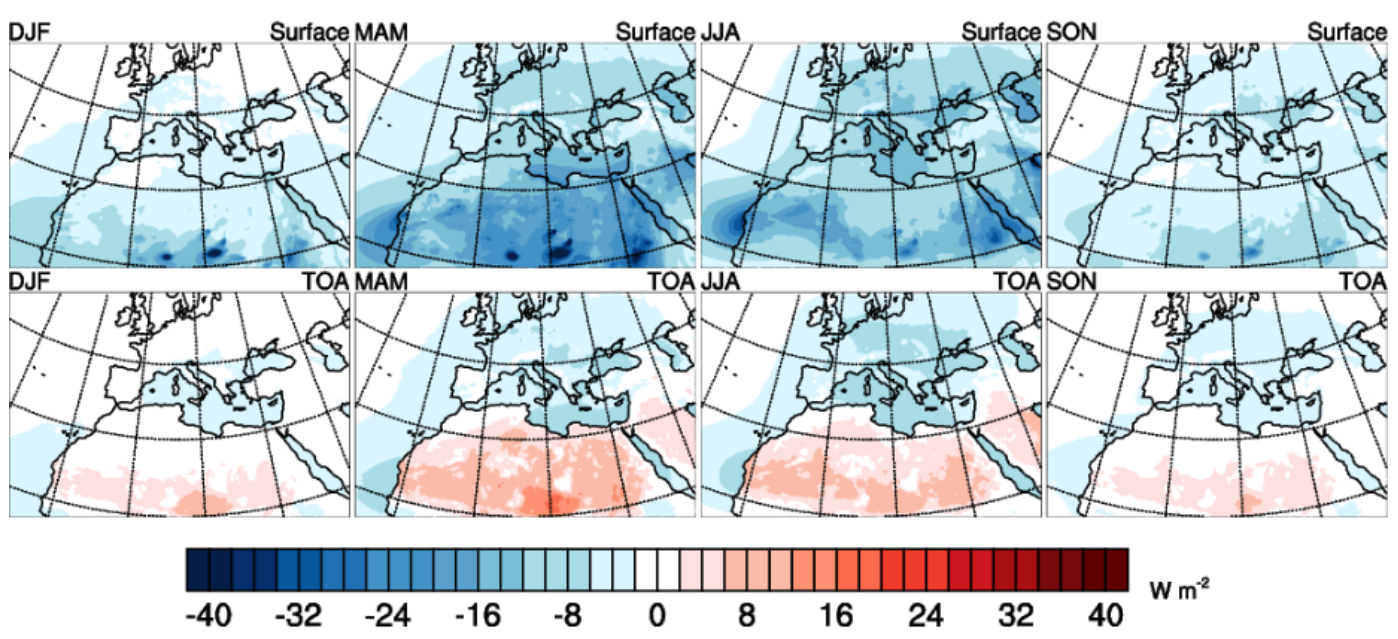

Figure 8. Mean SW DRF $\left(\mathrm{W} \mathrm{m}^{-2}\right.$ ) of all aerosols over the period 1971-2000 at the surface and at the TOA.

7.0 where sulfate particles have a contribution to the total AOD of about $16 \%$, comparable to that of nitrate (19\%) or primary sea salt (15\%) aerosols. Finally, natural aerosol contribution to the total AOD increases slightly between the two periods both over Europe and the Mediterranean Sea. For information, the increase in sea salt emissions over the Mediterranean Sea, particularly in spring and summer, is explained by the increase in sea surface temperature, on which these aerosol emissions directly depend, and not by a change in wind speed.

\subsection{Evolution of aerosol direct radiative forcing}

The evolution and variability of the different aerosol species over the Euro-Mediterranean region presented above is mainly dominated by the sulfate mass concentration decrease partially compensated by the nitrate concentration increase. This evolution would consequently impact the variability of the shortwave (SW) direct radiative forcing (DRF) exerted by the anthropogenic particles. This instantaneous aerosol radiative forcing, at the surface and TOA in SW and LW spectral ranges, is diagnosed using a double call (with and without aerosols) to the radiation scheme during the model simulation.

\subsubsection{Historical aerosol DRF}

Before studying the change in the DRF of the different particles between the historical (1971-2000) and the future period (2021-2050), we first analyse the SW DRF exerted by all aerosols over the historical period. The results are presented seasonally both at the surface and at the TOA in Fig. 8 and summarized in Table 3. Unless otherwise specified, the different presented direct radiative forcing values are calculated in all-sky conditions. Figure 8 shows that natural and
Table 3. Mean SW DRF $\left(\mathrm{W} \mathrm{m}^{-2}\right)$ of all aerosols over the period 1971-2000 at the surface and at the TOA over Europe, Mediterranean Sea and Africa.

\begin{tabular}{rlrrr}
\hline & & & Mediterranean \\
& & Europe & Sea & Africa \\
\hline \multirow{4}{*}{ Surface } & DJF & -2.1 & -4.3 & -7.2 \\
& MAM & -7.4 & -13.1 & -17.3 \\
& JJA & -9.2 & -11.9 & -12.1 \\
& SON & -4.2 & -5.5 & -5.8 \\
\cline { 2 - 5 } & Annual & -5.7 & -8.7 & -10.6 \\
& mean & & & \\
\cline { 2 - 5 } & DJF & -1.1 & -2.6 & 1.2 \\
& MAM & -4.0 & -5.9 & 5.3 \\
& JJA & -5.3 & -7.1 & 3.6 \\
& SON & -2.8 & -3.6 & 1.3 \\
\cline { 2 - 5 } & Annual & -3.3 & -4.8 & 2.8 \\
& mean & & & \\
\hline
\end{tabular}

anthropogenic aerosols, by absorbing and scattering solar radiation, cause an average estimated surface SW DRF of $-5.7 \mathrm{~W} \mathrm{~m}^{-2}$ over Europe, $-8.7 \mathrm{~W} \mathrm{~m}^{-2}$ over the Mediterranean Sea and $-10.6 \mathrm{~W} \mathrm{~m}^{-2}$ over North Africa. In comparison, some studies using multi-annual regional simulations have been carried out. For example, Nabat et al. (2015) showed a surface SW DRF over the period 2003-2009 on the order of $-14.7 \mathrm{~W} \mathrm{~m}^{-2}$ over Europe, $-20.9 \mathrm{~W} \mathrm{~m}^{-2}$ over the Mediterranean Sea and $-19.7 \mathrm{~W} \mathrm{~m}^{-2}$ over North Africa. Differences between this study's results and those presented here are largely explained by a different version of the atmospheric model between the two modelling exercises, but also by the non-inclusion of nitrate and ammonium aerosols and 


\section{(a) - SSP 5-8.5}

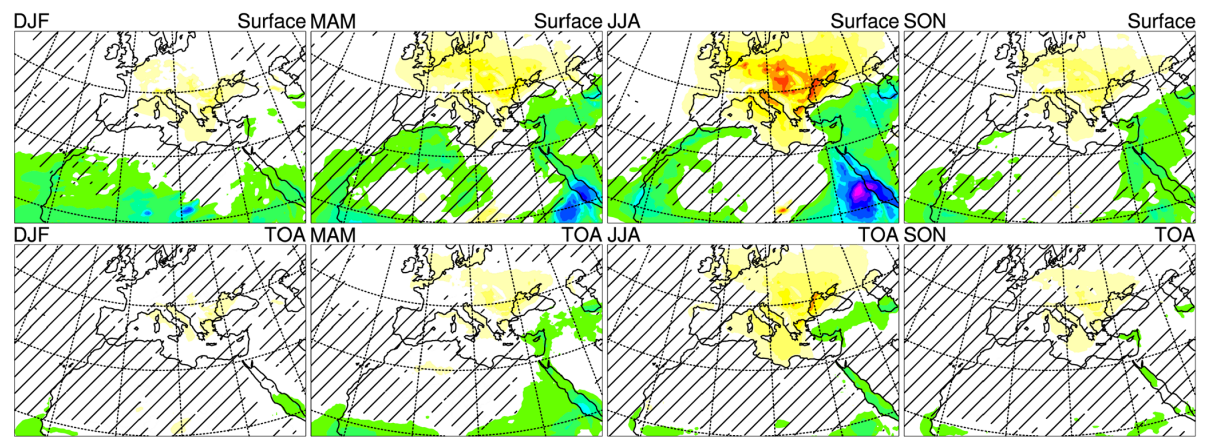

(b) - SSP 3-7.0

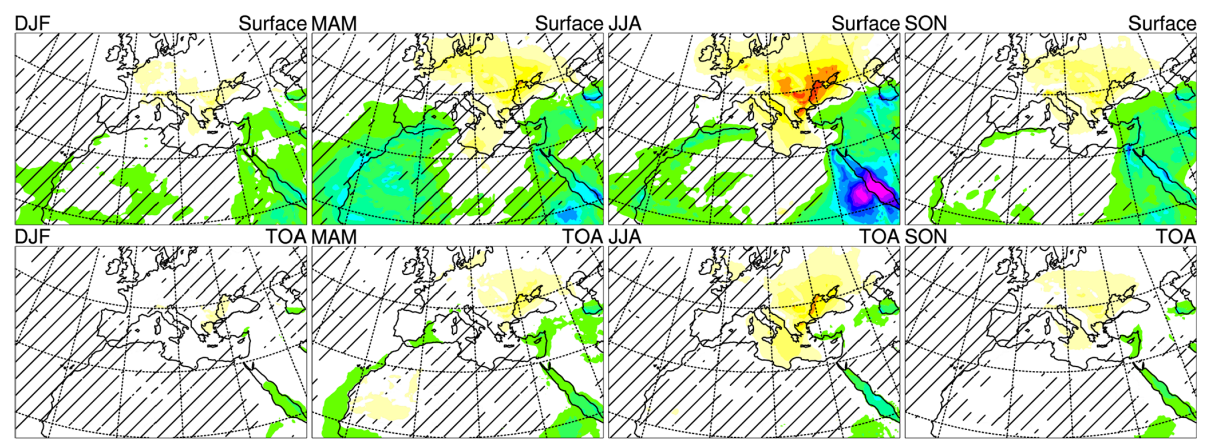

(c) - SSP 1-1.9
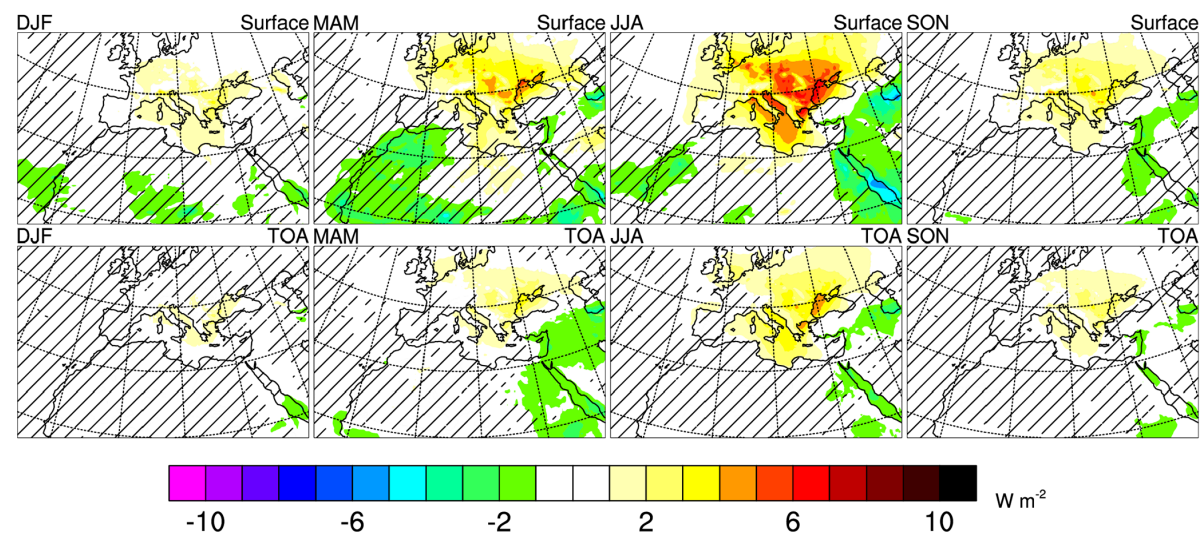

Figure 9. Mean aerosols SW DRF evolution $\left(\mathrm{W} \mathrm{m}^{-2}\right)$ at the surface and at the TOA between the historical period (1971-2000) and the future period (2021-2050) according to SSPs 5-8.5 (a), 3-7.0 (b) and 1-1.9 (c). The hatched areas are statically non-significant with a threshold of $10 \%$.

the use of an aerosols climatology in the study of Nabat et al. (2015). A study using the regional climate model RegCM, which includes an aerosol prognostic scheme for five species (sulfate, organic carbon, black carbon, dust and primary sea salt), showed a mean surface DRF over the period 2000-2009 close to that simulated here: on the order of $-13.6 \mathrm{~W} \mathrm{~m}^{-2}$ over the Mediterranean Sea and $-14.9 \mathrm{~W} \mathrm{~m}^{-2}$ over North Africa (Nabat et al., 2012). Benas et al. (2013) have shown a mean surface aerosol DRF between -15 and $-30 \mathrm{~W} \mathrm{~m}^{-2}$ in Crete over the period 2000-2010. Finally, the Papadimas et al. (2012) study indicates, on the basis of MODIS satellite data, a mean DRF over the Mediterranean basin on the order of $-16.5 \mathrm{~W} \mathrm{~m}^{-2}$ at the surface (period 2000-2007), with a maximum during spring and summer. Table 3 as well as Fig. 8 also show that the highest SW DRF simulated at the surface occurs during spring, especially for regions with high dust emissions $\left(-17.3 \mathrm{~W} \mathrm{~m}^{-2}\right.$ over Africa) and over the Mediterranean Sea $\left(-13.1 \mathrm{~W} \mathrm{~m}^{-2}\right)$ near the coasts. The results presented above are therefore fairly consistent with 
these various studies, both on the intensity and on the spatial and temporal distribution of historical surface SW DRF.

At the TOA, the aerosol SW DRF is also negative $\left(-3.3 \mathrm{~W} \mathrm{~m}^{-2}\right.$ over Europe and $-4.8 \mathrm{~W} \mathrm{~m}^{-2}$ over the Mediterranean Sea, on average) with a maximum in summer, except over North Africa where it is slightly positive $\left(+2.8 \mathrm{~W} \mathrm{~m}^{-2}\right)$ due to a high surface albedo over this region and the absorbing properties of mineral dust (single scattering albedo of dust fixed at 0.90 for the $550 \mathrm{~nm}$ wavelength in CNRM-ALADIN63). This result is consistent with the study of Bellouin et al. (2011), carried out with a global climate model, which shows a radiative forcing (direct and first indirect effect) on the order of $-4 \mathrm{~W} \mathrm{~m}^{-2}$ at the TOA over Europe for the year 2000. Moreover, over the period 20002007, Papadimas et al. (2012) estimated a DRF at the TOA of $-2.4 \mathrm{~W} \mathrm{~m}^{-2}$ over the Mediterranean basin as well as a positive DRF over desert areas of $+4.1 \mathrm{~W} \mathrm{~m}^{-2}$.

Whether on the surface or at the TOA, the CNRMALADIN63 model therefore simulates a historical aerosol SW DRF that is consistent with previous studies. Therefore, this model seems to be valid for studying the future evolution of this aerosol DRF.

\subsubsection{Future aerosol DRF}

Finally, Fig. 9 presents the total SW aerosol DRF difference between the historical (1971-2000) and the future (20212050) periods according to the three different scenarios previously presented. This figure shows a similar DRF evolution using the three different scenarios with a significant decrease in absolute terms at the surface and at the TOA over Europe, in particular during the summer over the Po Valley, the Benelux and Eastern Europe, of up to $6 \mathrm{~W} \mathrm{~m}^{-2}$. Figure A2 shows that this surface SW DRF decrease over Europe present in the CNRM-ALADIN63 model $\left(1.6 \mathrm{~W} \mathrm{~m}^{-2}\right.$ on average for the three scenarios) is also found with its forcing model (CNRM-ESM2-1, $2.8 \mathrm{~W} \mathrm{~m}^{-2}$ on average for the three scenarios). The differences between these two models are mainly due to the fact that nitrate and ammonium aerosols are not taken into account in the CNRM-ESM2-1 global model. Figure 9 shows that the total DRF decrease over Europe at the surface is $1.6 \mathrm{~W} \mathrm{~m}^{-2}$ on average with the SSP 5-8.5, 1.2 $\mathrm{W} \mathrm{m}^{-2}$ with the SSP 3-7.0 and $2.0 \mathrm{~W} \mathrm{~m}^{-2}$ with the SSP 1-1.9. The SSP 1-1.9 shows the largest decrease in total DRF over Europe, which is consistent with the total AOD evolution analysed previously. On the other hand, over North Africa, Fig. 9 shows an increase in the surface DRF in absolute terms, ranging from $0.5 \mathrm{~W} \mathrm{~m}^{-2}$ with the SSP $1-1.9$ to $1.4 \mathrm{~W} \mathrm{~m}^{-2}$ with the SSP 3-7.0. At the TOA, the same trends are found but with lower values on the order of $1 \mathrm{~W} \mathrm{~m}^{-2}$ over Europe and $0.2 \mathrm{~W} \mathrm{~m}^{-2}$ over North Africa. These changes in DRF are therefore consistent with the changes in total AOD presented previously. Moreover, these results are also consistent with Shindell et al. (2013), who showed a lower aerosol radiative forcing (direct and indirect effects) in 2030 than in 1980 over Europe with global climate models.

The evolution between the two periods of the SW DRF exerted at the surface by each aerosol type, which is diagnosed using several calls to the radiation scheme at each time step, is reported in Fig. 10. The same results at the TOA are presented in Fig. A3. Showing the same trends as the results observed at the surface, but with lower values, only the evolution of the SW DRF exerted at the surface by each aerosol type will be discussed here. As showed previously, the results clearly indicate, in absolute terms, that the aerosol DRF decreases over Europe between the two periods. This is largely due to sulfate and organic carbon aerosols, which represent a mean DRF decrease at the surface of $2.6 \mathrm{~W} \mathrm{~m}^{-2}$. On the other hand, nitrate and ammonium aerosols partially compensate the sulfate and organic carbon DRF decrease with a contribution of $1.4 \mathrm{~W} \mathrm{~m}^{-2}$ on average for the three SSPs. The evolution of the different aerosol DRF estimated here is consistent with results obtained at the global scale by Hauglustaine et al. (2014). Our results concerning the nitrate DRF are also consistent with other studies carried out at the global scale. Indeed, the global nitrate DRF is estimated to be between -0.02 and $-0.19 \mathrm{~W} \mathrm{~m}^{-2}$ (Adams et al., 2001; Jacobson, 2001; Liao and Seinfeld, 2005; Bauer et al., 2007; Xu and Penner, 2012; IPCC, 2013; Myhre et al., 2013a) and is estimated to be between -0.4 and $1.3 \mathrm{~W} \mathrm{~m}^{-2}$ by the end of the century, becoming the aerosol with the highest cooling effect (Adams et al., 2001; Bellouin et al., 2011). Figure 10 also shows that the natural aerosol DRF remains relatively stable between the two periods. Over the Mediterranean Sea, Fig. 10 shows a surface aerosol DRF evolution close to the one simulated over Europe with a sulfate and organic carbon DRF decrease of about $2.6 \mathrm{~W} \mathrm{~m}^{-2}$, which is associated with an nitrate and ammonium DRF increase of about $1.7 \mathrm{~W} \mathrm{~m}^{-2}$. Both over Europe and the Mediterranean Sea, the largest sulfate and organic carbon DRF decrease occurs with the SSP 1-1.9 (2.8 $\mathrm{W} \mathrm{m}^{-2}$ on average over Europe and $3.0 \mathrm{~W} \mathrm{~m}^{-2}$ over the Mediterranean Sea). As presented previously, this specific scenario presents the largest concentration decrease of these particles over these two regions. Concerning North Africa, Fig. 10 indicates a slight total DRF increase, which is partly due to an increase of nitrate and ammonium DRF (of about $0.6 \mathrm{~W} \mathrm{~m}^{-2}$ for the three scenarios) but also for black carbon aerosols, especially for SSPs 3-7.0 and 5-8.5 during summer and autumn $\left(0.3-0.4 \mathrm{~W} \mathrm{~m}^{-2}\right.$ on annual average). In addition, this total DRF increase over North Africa is also due to a moderate dust DRF increase, which is about $0.3-0.4 \mathrm{~W} \mathrm{~m}^{-2}$ with the three scenarios over this region. The maximum of this dust DRF increase occurs during the months of May and June for the three scenarios and can reach $1.5 \mathrm{~W} \mathrm{~m}^{-2}$. 


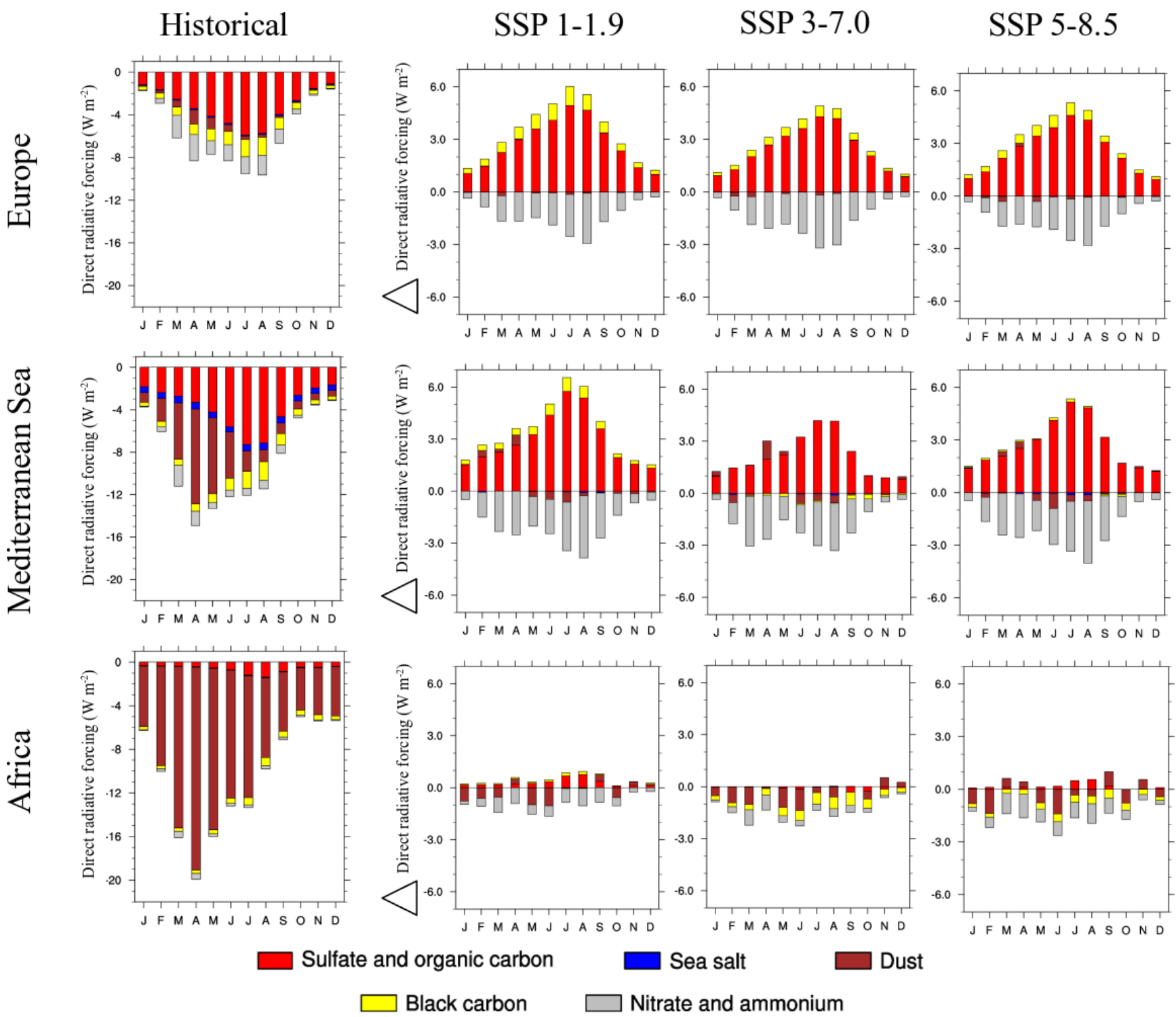

Figure 10. Surface SW DRF evolution ( $\mathrm{W} \mathrm{m}^{-2}$ ) of sulfate and organic carbon (in red), sea salt (in blue), dust (in brown), black carbon (in yellow) and nitrate and ammonium (in grey) between the historical period (1971-2000) and the future period (2021-2050) according to SSPs $1-1.9,3-7.0$ and 5-8.5.

\section{Future Euro-Mediterranean climate sensitivity to anthropogenic aerosols}

The evolution of the surface mass concentration, AOD and DRF of the different aerosols discussed previously are expected to have some significant impacts on the future EuroMediterranean climate. As primary natural sea spray and mineral dust aerosols are characterized by moderate changes between the historical and the future period, only the anthropogenic aerosol impact will be studied here. Furthermore, as the differences between the scenarios are small, only the SSP 5-8.5 will be discussed in this section for clarity reasons.

\subsection{Future climate simulated by CNRM-ALADIN63}

First of all, Fig. 11 presents the changes in surface SW radiation (panel a), surface temperature (panel b), precipitation (panel c) and surface wind speed (panel d) between the historical and future periods over the Euro-Mediterranean region for the SSP 5-8.5. Panel (a) shows a sharp surface SW radiation increase over Europe between the two periods (1971-2000 and 2021-2050) that is on the order of $5 \mathrm{~W} \mathrm{~m}^{-2}$ on annual average. Figure 11a also indicates a strong seasonal variability with a higher surface radiation increase in summer $\left(7.5 \mathrm{~W} \mathrm{~m}^{-2}\right)$. Concerning surface temperatures, panel (b) indicates a significant increase over the Euro-Mediterranean region. On annual average, the increase 
(a) - Surface radiation
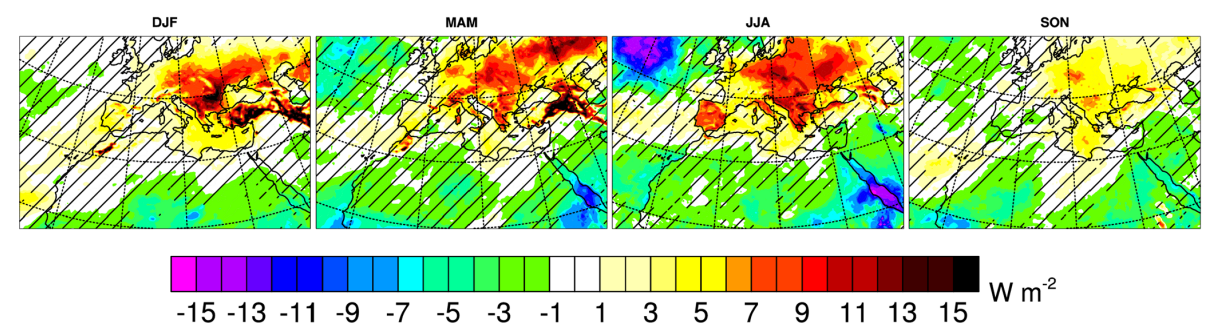

(b) - Surface temperature

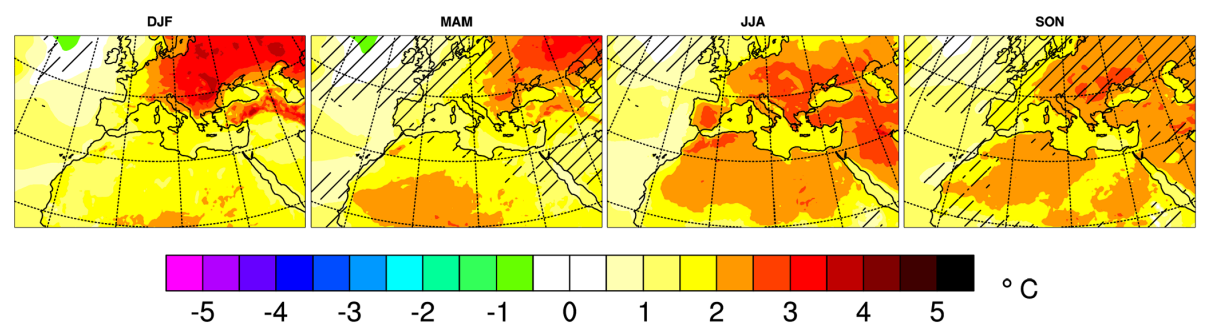

(c) - Precipitations

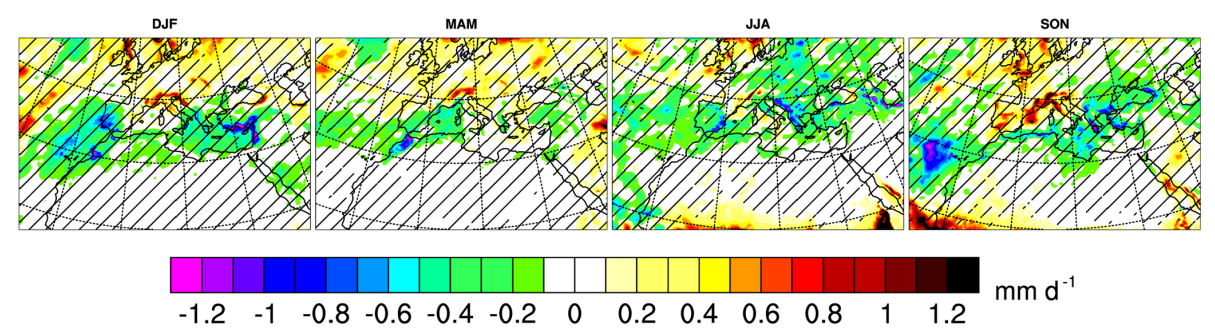

(d) - Near-surface (10 m) wind speed
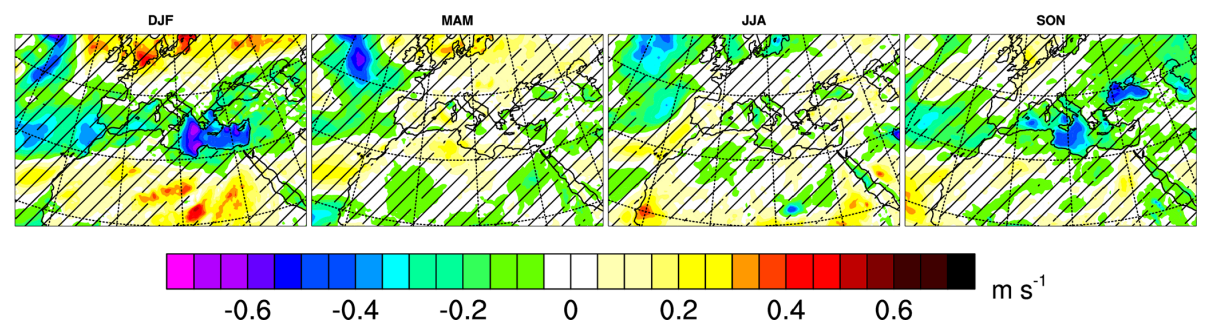

Figure 11. Surface radiation $\left(\mathrm{W} \mathrm{m}^{-2}, \mathbf{a}\right)$, surface temperature $\left({ }^{\circ} \mathrm{C}, \mathbf{b}\right)$, precipitation $\left(\mathrm{mm} \mathrm{d}^{-1}, \mathbf{c}\right)$ and surface wind speed $\left(\mathrm{m} \mathrm{s}{ }^{-1}, \mathbf{d}\right)$ evolution between the periods 1971-2000 and 2021-2050 for the SSP 5-8.5. The hatched areas are statically non-significant with a threshold of $10 \%$.

between the two periods is about $2.2^{\circ} \mathrm{C}$ over Europe, $1.7^{\circ} \mathrm{C}$ over the Mediterranean Sea and $1.9^{\circ} \mathrm{C}$ over Africa. The strongest temperature increase over Europe is simulated during the winter, with an average of $2.5^{\circ} \mathrm{C}$ and a maximum of $4^{\circ} \mathrm{C}$ over Eastern Europe. Over Africa, the maximum temperature increase occurs in summer with an average of $2{ }^{\circ} \mathrm{C}$. These results are consistent with different studies such as that of Jacob et al. (2014), Boé et al. (2020) or Coppola et al. (2021). This last study shows, for the RCP 8.5 or the SSP 58.5 , a median warming in winter of $2.5^{\circ} \mathrm{C}$ for the CMIP5 ensemble and of $3.8^{\circ} \mathrm{C}$ for CMIP6 over Central Europe for the middle of the century (2041-2070) relative to 1981-2010.
Over the Mediterranean, they have shown a smaller warming between 2 and $2.5^{\circ} \mathrm{C}$. Finally, Coppola et al. (2021) also show a summer warming that is similar to that shown in Fig. 11 with a maximum signal over the Mediterranean land regions. Moreover, the ENSEMBLES project results show a temperature increase from 3 to $4.5^{\circ} \mathrm{C}$, also more pronounced in winter, with the A1B scenario over this region between 1971-2000 and 2021-2050 (Hewitt, 2004; van der Linden and Mitchell, 2009). Concerning precipitation and surface wind speed, except during winter, Fig. 11c and d shows few areas with significant changes. These results therefore present a higher uncertainty than temperatures. Nevertheless, 

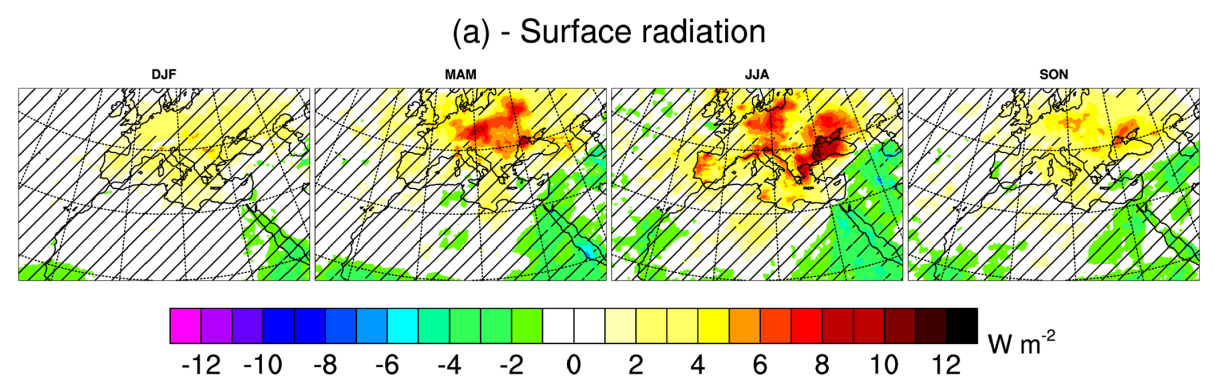

(b) - Surface temperature

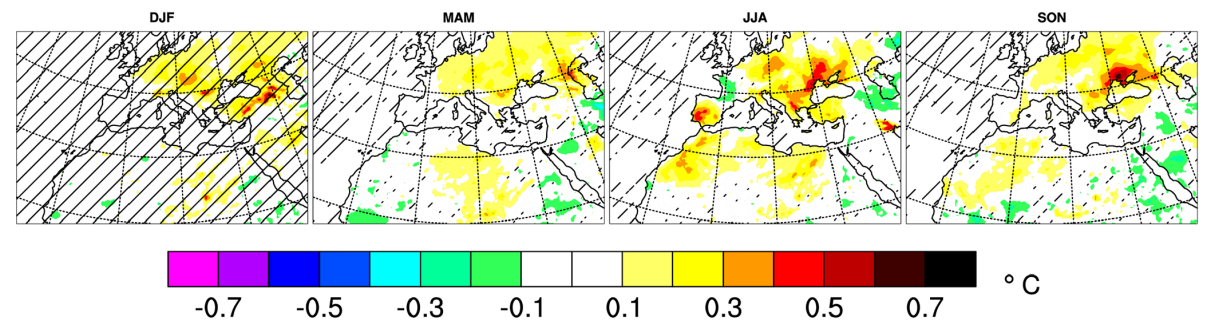

(c) - Precipitations

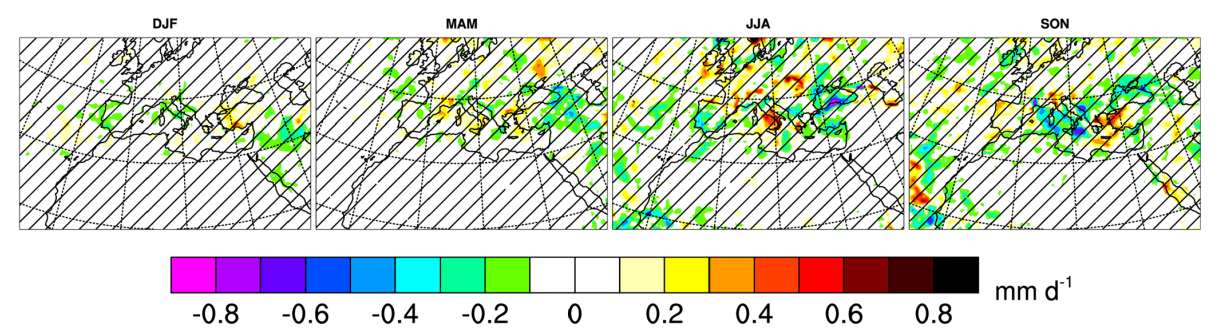

(d) - Near-surface $(10 \mathrm{~m})$ wind speed
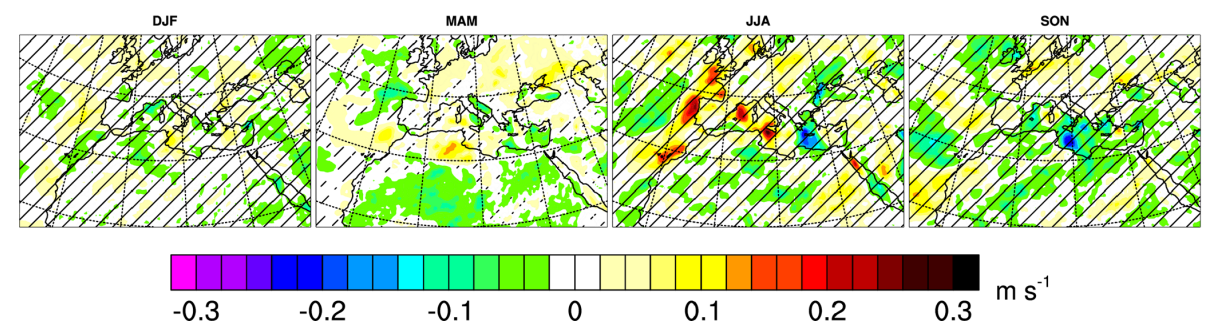

Figure 12. Anthropogenic aerosol role (difference between SSP585 and SSP585cst) in surface radiation (a), surface temperature (b), precipitation (c) and surface wind speed (d) changes between the periods 1971-2000 and 2021-2050. The hatched areas are statically non-significant with a threshold of $10 \%$.

Fig. 11 shows an average rainfall decrease of about $5 \%$ (2\% for surface wind speed) over the Mediterranean Sea between the period 1971-2000 and the period 2021-2050 with a maximum of $10 \%$ (5\% for surface wind speed) in winter. Over Europe, and mainly in the northern part of Europe, an increase in precipitation can be observed, with a maximum of $1 \mathrm{~mm} \mathrm{~d}^{-1}$ in the Alps. The only season with a decrease in precipitation throughout Europe is the summer, with an average decrease of $0.2 \mathrm{~mm} \mathrm{~d}^{-1}$. Similar results concerning precipitation are observed in different studies (Jacob et al., 2014; Boé et al., 2020; Coppola et al., 2021) as well as in the
ENSEMBLES project from scenario A1B. Indeed, Coppola et al. (2021) have shown, for the middle of the century and in winter, a median precipitation increase of $10 \%-12 \%$ over Central Europe and a median negative change of $5 \%$ over the Mediterranean for the EURO-CORDEX, the CMIP5 and the CMIP6 ensembles. For the summer period, they showed a negative change of precipitation spanning the range from $4 \%$ (EURO-CORDEX) to - $10 \%$ (CMIP6) over Central Europe and from $-10 \%$ to $-20 \%$ over the Mediterranean. Finally, compared to these different ensembles, the simulation used 
in this study is therefore an average simulation, close to the CMIP5 ensemble.

The question of the part of these different changes that can be explained by the evolution of aerosols will now be addressed. For that, Fig. 12 shows the role of anthropogenic aerosols, by the difference between SSP585 and SSP585cst simulations, in surface radiation (panel a), surface temperature (panel b), precipitation (panel c) and surface wind speed (panel d) changes previously seen between the historical and the future period. Panel (a) shows that the various anthropogenic aerosols are responsible for about $65 \%$ of the radiation increase, on annual average over Europe, between the periods 1971-2000 and 2021-2050. These results are consistent with the Nabat et al. (2014) study, which shows that aerosol changes can explain, over the period 1980-2012, $81 \pm 16 \%$ of the brightening over Europe. Concerning the impact of anthropogenic aerosols on the surface temperature increase, Fig. 12b shows that they can contribute about $0.2^{\circ} \mathrm{C}$ on average and up to $0.5^{\circ} \mathrm{C}$ locally in summer. The anthropogenic aerosol evolution explains about $6 \%$ of the expected warming over Europe on annual average with a maximum of $20 \%$ over certain regions such as the northern Black Sea in summer. The surface radiation and temperature changes between the historical and future period over the Euro-Mediterranean region, as well as the part of these changes attributable to anthropogenic aerosols, are summarized in Table 4. In the Boé et al. (2020) and Gutiérrez et al. (2020) studies, the authors have also shown that time-varying anthropogenic aerosol forcing plays an important role on radiation and therefore temperature changes. Indeed Boé et al. (2020) showed, on average over Europe, that aerosols can explain roughly $0.5^{\circ} \mathrm{C}$ of the $1.8^{\circ} \mathrm{C}$ warming (i.e. $30 \%$ of the warming) in the 2021-2050 period with the RCP 8.5. Moreover, Fig. 12b also shows a strong regional variability in terms of anthropogenic aerosol impact on surface temperature, especially during the summer season. Two maxima are simulated over Central Europe and over the Iberian Peninsula that will be studied in more detail below.

Concerning the role of anthropogenic aerosols in precipitation changes, Boé et al. (2020) show that the anthropogenic aerosol evolution could lead to an increase in precipitation over the northern half of Europe. However, in the present study, results about the impact of anthropogenic aerosols on precipitation or on surface wind speed changes showed no significant signals over the Euro-Mediterranean region (see Fig. 12c and d for details).

\subsection{Central Europe}

The summer is the season most impacted by the anthropogenic aerosol evolution as shown in the previous results. For this reason, only this season will be discussed in the rest of this study. Figures 13 and 14 show average differences of several parameters between the SSP585 and the SSP585cst simulations for the months of June, July and August over the
Euro-Mediterranean region. During the summer, the first extra warming due to anthropogenic aerosols occurs over Central Europe and shows an extra warming of about $0.2^{\circ} \mathrm{C}$ on average over this region with a maximum of $0.6^{\circ} \mathrm{C}$ over the north of the Black Sea (Fig. 13a). On average, this temperature increase corresponds to $10 \%$ of the expected warming over this region during this season. Figure 13 also indicates that this extra warming over Central Europe is well correlated with a surface radiation increase, also due to the anthropogenic aerosol evolution, of $5.8 \pm 1.2 \mathrm{~W} \mathrm{~m}^{-2}$ on average over this region (Fig. 13b).

Figure 13 shows that the surface solar radiation increase over Central Europe can be explained by a total aerosol direct radiative forcing decrease at the surface on the order of $4.4 \pm 0.2 \mathrm{~W} \mathrm{~m}^{-2}$ (Fig. 13c) correlated to a positive effective radiative forcing due to aerosol-radiation interactions (ERFari) of $2.7 \pm 0.1 \mathrm{~W} \mathrm{~m}^{-2}$ (Fig. 13d) over this region. The ERF is a useful measure of defining the impact on the Earth's energy imbalance to a radiative anthropogenic or natural perturbation (Myhre et al., 2013b; Forster et al., 2016; Smith et al., 2020) and is calculated in this study at the TOA with the method recommended in Ghan (2013). As shown in Fig. 13e, the direct radiative forcing decrease over Central Europe is mainly due to the anthropogenic AOD decrease $(-0.1$ on average, i.e. a decrease of about $40 \%)$, largely dominated by the decrease in loads of sulfate particles. In addition, the surface solar radiation increase of $2.6 \%$ over Central Europe is well correlated with the clouds optical depth (COD) decrease of about $8.7 \%$, equivalent to $-1.3 \pm 0.3$, as shown in Fig. 14a. This change in COD is mainly due to the effective cloud droplet radius increase of about $1.2 \mathrm{~m}$ over this region (Fig. 14c). The COD decrease and the effective cloud droplet radius increase over this region is caused by the sulfate concentration drop, which is illustrated by the sulfate AOD decline of about -0.14 between the historical and future periods over Central Europe. Recall that in the CNRMALADIN63 model, only the first indirect radiative effect of sulfate, organic carbon and sea salt aerosols is taken into account (Michou et al., 2020). The effective droplet radius and COD are therefore directly dependent on the concentration of these different aerosols types. Given the weak organic carbon and sea salt aerosol evolution between the two periods (1971-2000 and 2021-2050), changes in COD observed are therefore largely dependent on the sulfate aerosol decrease. In detail, the region of Central Europe studied here could be divided into two more specific regions where the surface solar radiation increase causes are somewhat different. Indeed, the surface solar radiation increase over the Black Sea region is due to both the direct radiative forcing decrease and the COD decrease, while over Germany it is mostly due to the COD decrease.

Finally, the extra warming due to anthropogenic aerosols observed over Central Europe is therefore due to a combination of aerosol-radiation (direct aerosol effect) and aerosolcloud (indirect aerosol effect) interaction processes. The var- 
(a) - Surface temperature

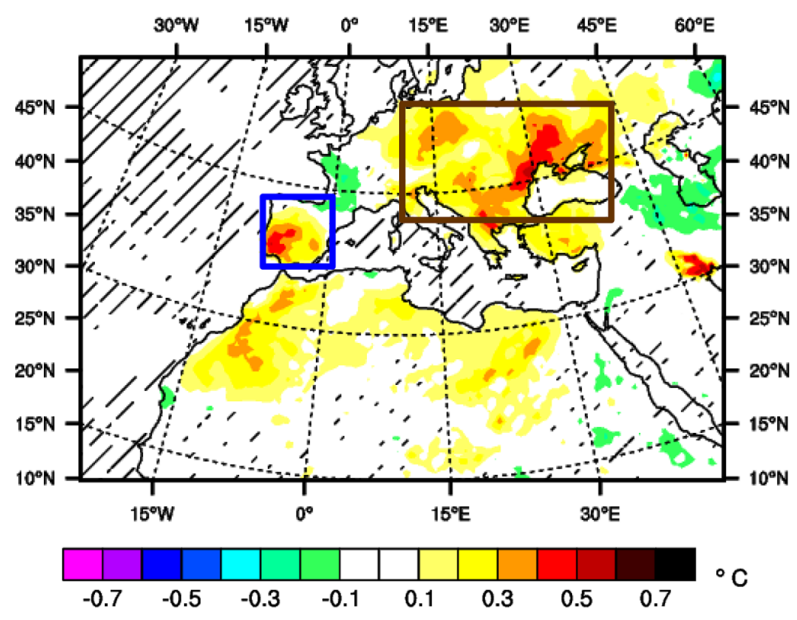

(c) - Surface direct radiative forcing

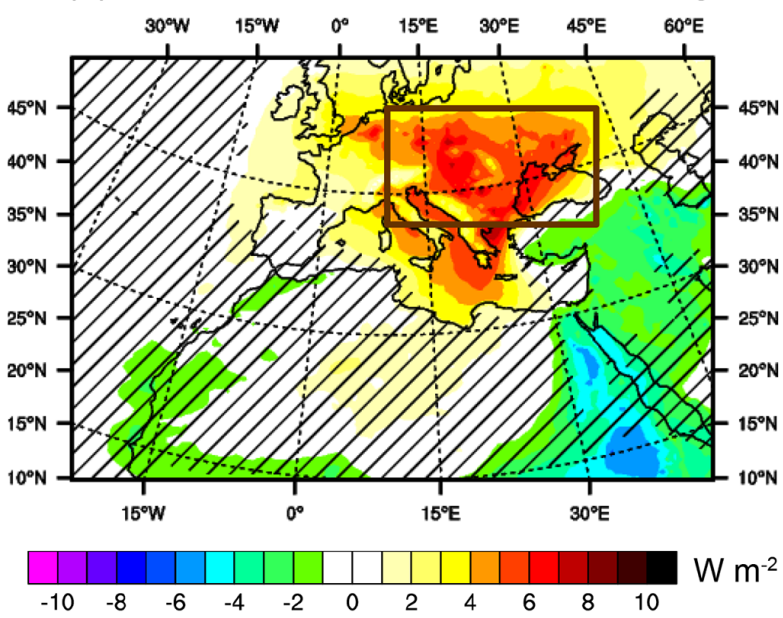

(b) - Surface radiation

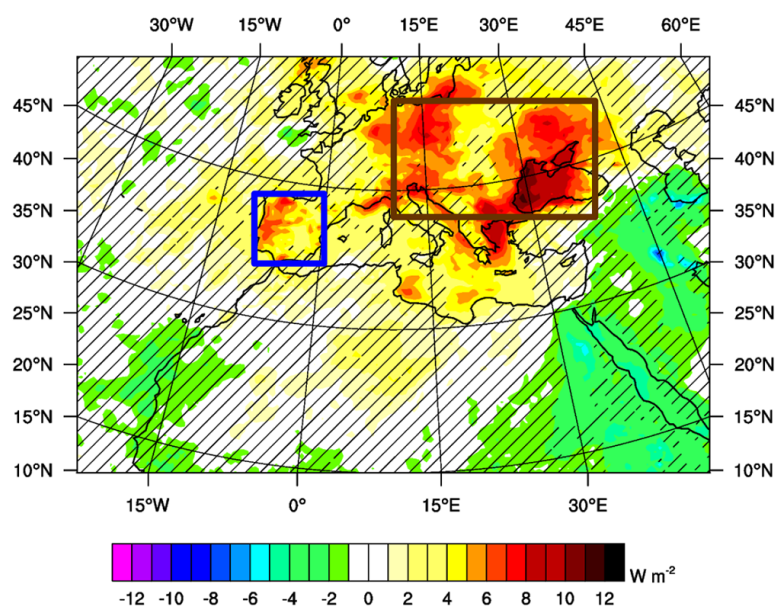

(d) - ERFari
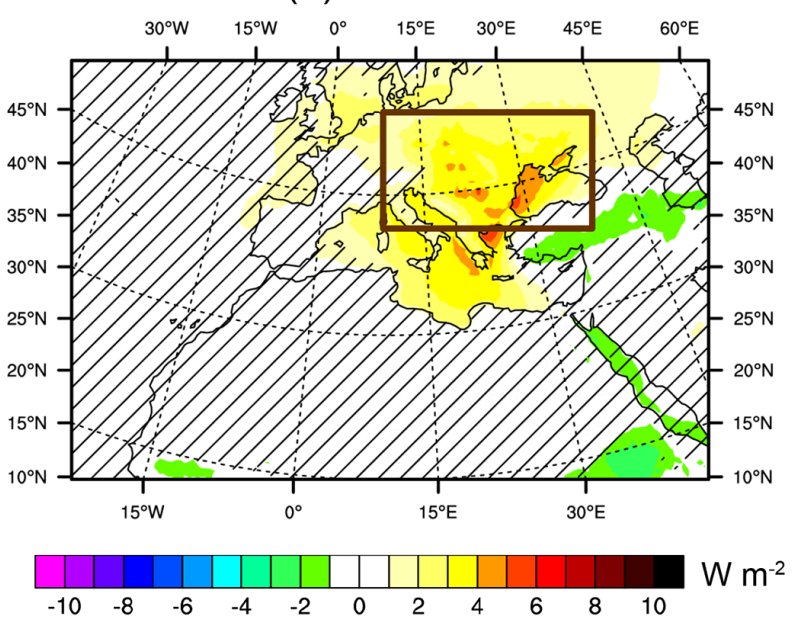

(e) - Total AOD

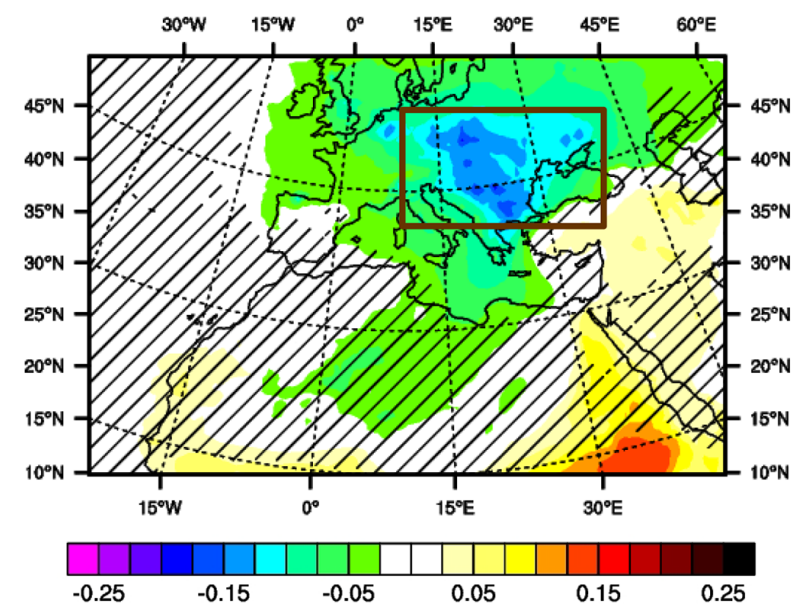

Figure 13. Mean differences for the months of June, July and August between SSP585 and SSP585cst simulations over the period 2021-2050 for the surface temperature $\left({ }^{\circ} \mathrm{C}, \mathbf{a}\right)$, the surface radiation $\left(\mathrm{W} \mathrm{m}^{-2}, \mathbf{b}\right)$, the surface direct radiative forcing $\left(\mathrm{W} \mathrm{m}^{-2}, \mathbf{c}\right)$, the effective radiative forcing due to aerosol-radiation interactions (ERFari, $\mathrm{W} \mathrm{m}^{-2}, \mathbf{d}$ ) and the total AOD (e). The brown frame represents Central Europe and the blue frame locates the Iberian Peninsula. The hatched areas are statically non-significant with a threshold of $10 \%$. 
(a) - Clouds optical depth

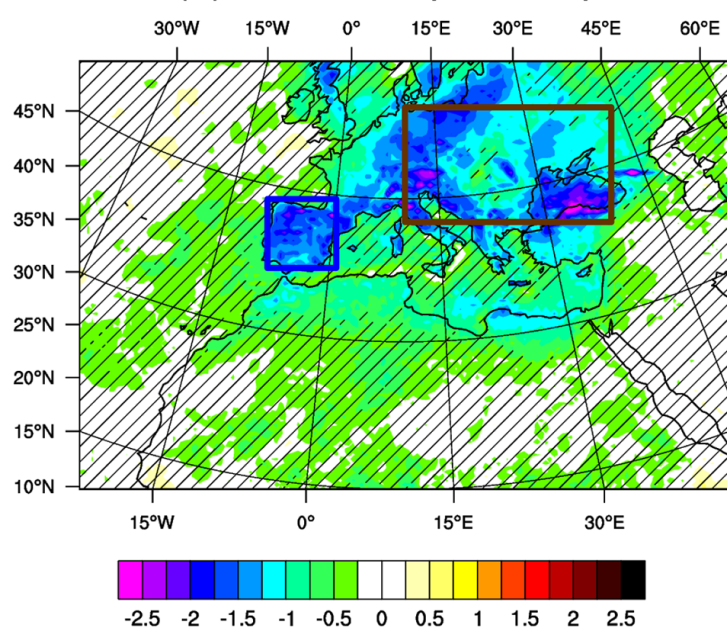

(c) - Effective droplet radius (b) - ERFaci

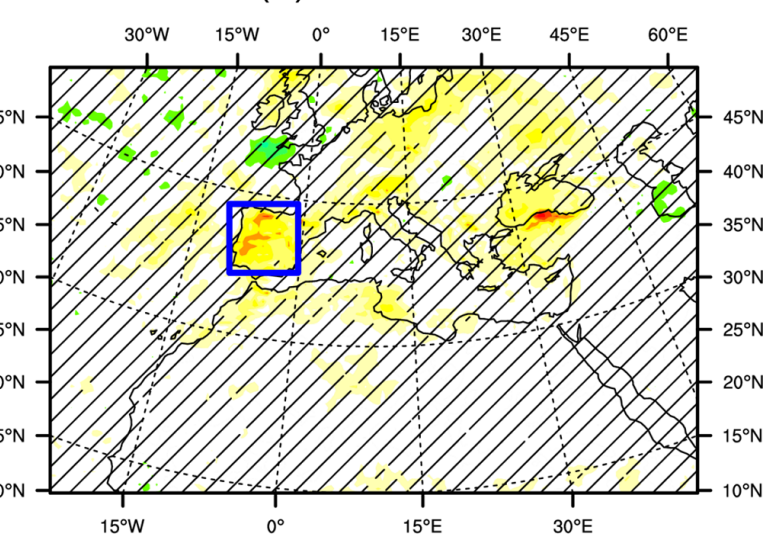

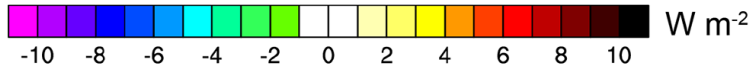

(d) - Cloud cover

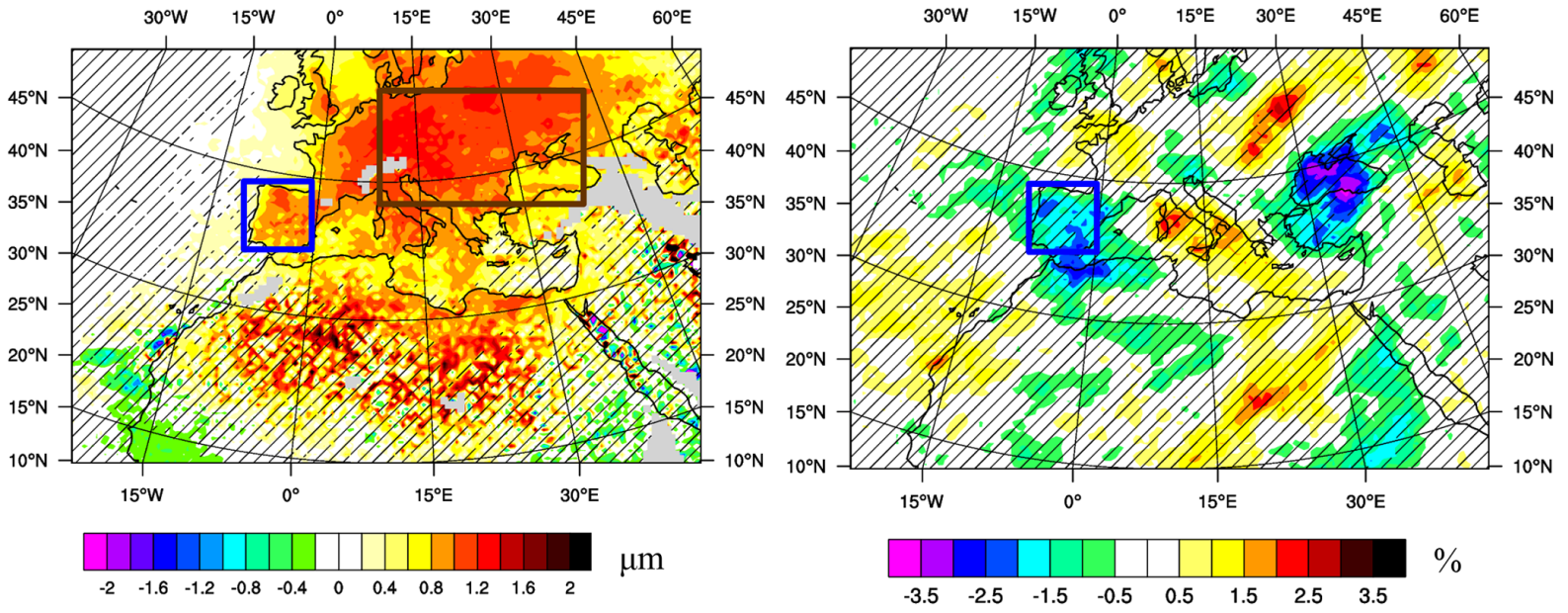

(e) - Sea-level pressure

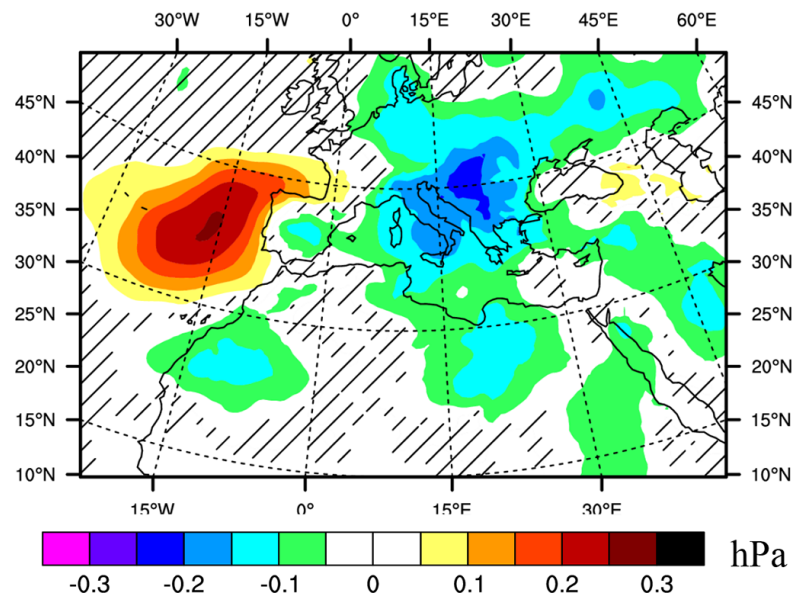

Figure 14. Mean differences for the months of June, July and August between SSP585 and SSP585cst simulations over the period 2021-2050 for the cloud optical depth (a), the effective radiative forcing due to aerosol-cloud interactions (ERFaci, $\mathrm{W} \mathrm{m}^{-2}, \mathbf{b}$ ), the effective droplets radius $(\mu \mathrm{m}, \mathbf{c})$, the cloud cover $(\%, \mathbf{d})$ and the sea-level pressure $(\mathrm{hPa}, \mathbf{e})$. The brown frame represents Central Europe and the blue frame locates the Iberian Peninsula. The hatched areas are statically non-significant with a threshold of $10 \%$. 
Table 4. Average differences between the SSP585 and Hist simulations showing the surface radiation $\left(\mathrm{W} \mathrm{m}^{-2}\right)$ and the surface temperature $\left({ }^{\circ} \mathrm{C}\right)$ increase over Europe, the Mediterranean Sea and Africa between the periods 1971-2000 and 2021-2050 and between the SSP585 and SSP585cst simulations showing the aerosols contribution to this brightening $\left(\mathrm{W} \mathrm{m}^{-2}\right.$ and \%) and to this surface warming $\left({ }^{\circ} \mathrm{C}\right.$ and $\left.\%\right)$.

\begin{tabular}{|c|c|c|c|c|c|c|c|}
\hline & & \multicolumn{2}{|c|}{ Europe } & \multicolumn{2}{|c|}{ Mediterranean Sea } & \multicolumn{2}{|c|}{ Africa } \\
\hline & & SSP585-Hist & SSP585-SSP585cst & SSP585-Hist & SSP585-SSP585cst & SSP585-Hist & SSP585-SSP585cst \\
\hline \multirow{5}{*}{ 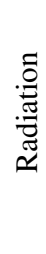 } & DJF & 5.3 & $2.4(45 \%)$ & 3.0 & $1.6(53 \%)$ & -1.3 & $-0.2(15 \%)$ \\
\hline & MAM & 5.8 & $4.1(71 \%)$ & 1.6 & $1.4(87 \%)$ & -2.2 & $-0.6(27 \%)$ \\
\hline & JJA & 7.5 & $4.7(63 \%)$ & 2.5 & $3.5(140 \%)$ & -2.6 & $-0.3(11 \%)$ \\
\hline & SON & 3.2 & $3.0(94 \%)$ & 1.6 & $1.5(94 \%)$ & -1.8 & $-0.4(20 \%)$ \\
\hline & $\begin{array}{l}\text { Annual } \\
\text { mean }\end{array}$ & 5.4 & $3.5(65 \%)$ & 2.2 & $2.0(91 \%)$ & -2.0 & $-0.4(20 \%)$ \\
\hline \multirow{5}{*}{ 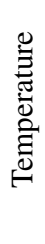 } & DJF & 2.5 & $0.12(5 \%)$ & 1.7 & $-0.005(-0.3 \%)$ & 1.6 & $0.01(0.6 \%)$ \\
\hline & MAM & 1.7 & $0.12(7 \%)$ & 1.5 & $0.002(0.1 \%)$ & 1.8 & $0.02(1.1 \%)$ \\
\hline & JJA & 2.3 & $0.16(7 \%)$ & 1.8 & $0.01(0.6 \%)$ & 2.0 & $0.06(3 \%)$ \\
\hline & SON & 2.1 & $0.12(6 \%)$ & 1.7 & $-0.006(-0.3 \%)$ & 1.9 & $0.02(1 \%)$ \\
\hline & $\begin{array}{l}\text { Annual } \\
\text { mean }\end{array}$ & 2.2 & $0.13(6 \%)$ & 1.7 & $0.001(0.1 \%)$ & 1.9 & $0.03(1.5 \%)$ \\
\hline
\end{tabular}

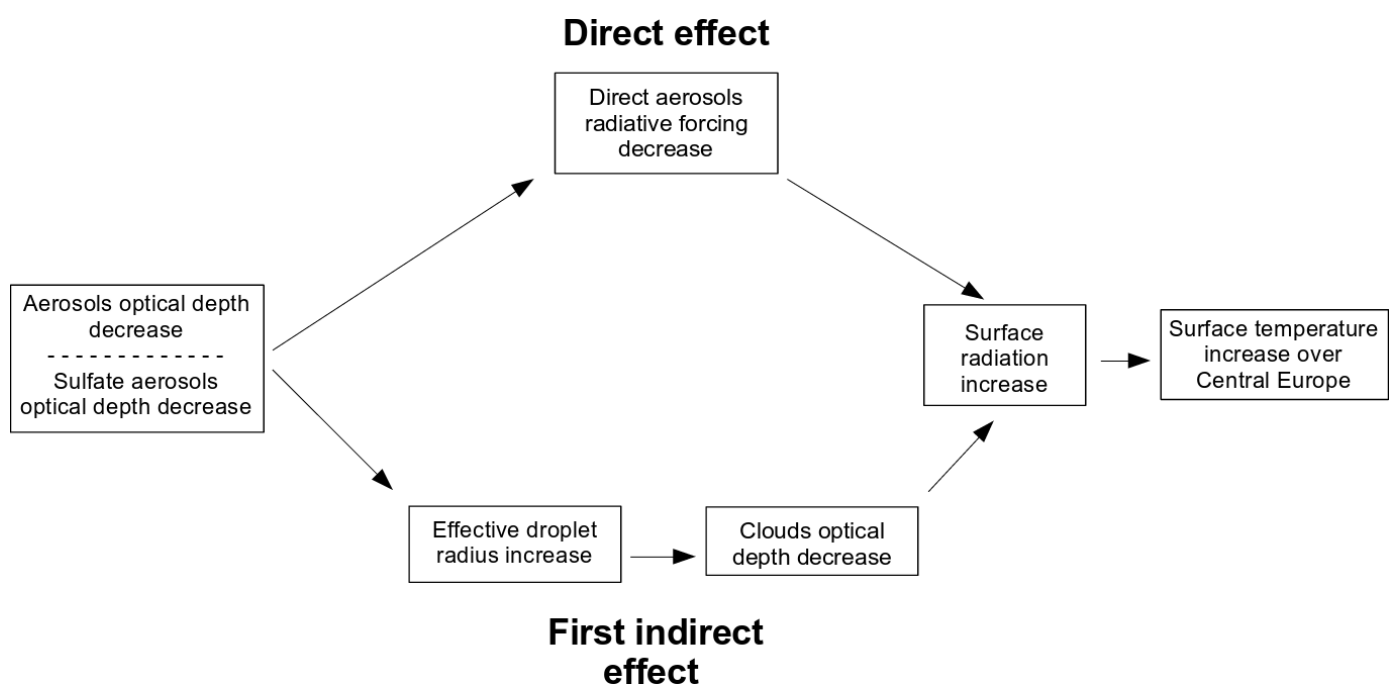

Figure 15. Summary of the anthropogenic aerosol role on the projected surface temperature increase over Central Europe in summer between the periods 1971-2000 and 2021-2050.

ious parameters responsible for the temperature increase over this region are summarized in Fig. 15.

\subsection{Iberian Peninsula and western France}

As previously mentioned, Fig. 13a also highlights a second extra warming due to anthropogenic aerosols on the order of $0.2^{\circ} \mathrm{C}$ occurring over the Iberian Peninsula. This warming observed during the summer is correlated here with a surface solar radiation rise of about $4.2 \pm 1.9 \mathrm{~W} \mathrm{~m}^{-2}$ (Fig. 13b). This increase can be explained over this region by a decrease of COD that is on the order of $-1.3 \pm 0.3$ on average over the Iberian Peninsula (Fig. 14a). This COD change leads to a positive ERFaci over this region $\left(2.6 \pm 1.1 \mathrm{~W} \mathrm{~m}^{-2}\right)$ through the decrease in radiative fluxes at the TOA (Fig. 14b). As mentioned previously, the COD decrease is mainly caused by an effective droplet radius increase of about $0.8 \pm 0.1 \mathrm{~m}$ (Fig. 14c) due, as before, to the sulfate mass concentration decrease between the historical and future period. In addition, the surface solar radiation increase observed over the Iberian Peninsula can also be explained by an atmospheric dynamics change as shown in Figs. 14d and 16. Indeed, Fig. $14 \mathrm{~d}$ shows a cloud cover decrease of $-1.7 \pm 1.2 \%$ on average over this region, which partly explains the simulated surface solar radiation increase. Figure A4 shows that this cloud cover decrease present in the CNRM-ALADIN63 


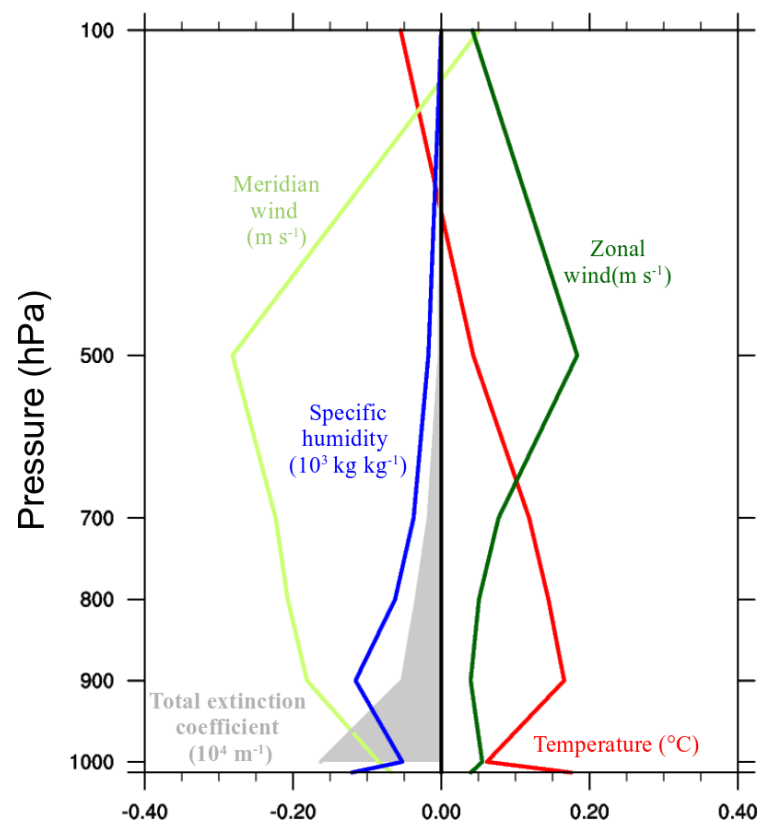

Figure 16. Vertical profile, obtained by the difference between SSP585 and SSP585cst simulations, of the temperature $\left({ }^{\circ} \mathrm{C}\right)$, the total extinction coefficient $\left(10^{4} \mathrm{~m}^{-1}\right)$, the meridional and zonal wind $\left(\mathrm{m} \mathrm{s}^{-1}\right)$ and the specific humidity $\left(10^{3} \mathrm{Kg} \mathrm{Kg}^{-1}\right)$ over the Iberian Peninsula for the months of June, July and August.

model is also found with its forcing model (CNRM-ESM21) as well as with the average of the different members carried out with this ESM model. Besides, Fig. 16, which shows the vertical profile of different parameters such as temperature or specific humidity obtained by the difference between SSP585 and SSP585cst simulations, also shows a surface-specific humidity decrease of about $1 \%$ or $2 \%$ that is due to the atmospheric dynamics modification. This surfacespecific humidity decrease, which thus generates drier air in the lower layers combined with a cloud cover decrease, directly contributes to the extra warming over the Iberian Peninsula. Figure 14e highlights the presence of an anticyclonic circulation anomaly over the near Atlantic, which may explain in part the cloud cover and the surface-specific humidity decrease over the Iberian Peninsula. In summary, the extra warming observed over the Iberian Peninsula is here due to the first indirect aerosol effect but also to an atmospheric dynamics change (semi-direct aerosol effect). As before, the various parameters responsible for the extra warming over this region are summarized in Fig. 17.

Finally, Fig. 13a shows a more particular case over western France, where a moderate surface temperature decrease can be observed despite an extra surface radiation increase over this region (Fig. 13b). In this case, the surface temperature decrease can only be explained by a change in atmospheric dynamics (semi-direct aerosol effect), which results in a fresh air supply from the ocean to western France. The different cases studied here during the summer for the SSP
5-8.5 clearly show that the regional contrasts in terms of anthropogenic aerosol impact on surface temperature changes between the historical and future period can be explained by various aerosol radiative effects.

\section{Conclusions}

This study deals with the evolution of different aerosols over the Euro-Mediterranean region between the historical period 1971-2000 and the future period 2021-2050 according to three different scenarios representing a wide range of possible futures. This study shows a total AOD decrease of about $35 \%$ over Europe, which is mainly due to the sulfur dioxide emissions decrease and consequently to the sulfate AOD reduction. The study also shows that this sulfate AOD decrease is nevertheless compensated, at $30 \%$, by the nitrate and ammonium particles optical depth increase. These nitrate aerosols furthermore become the main contributor to total AOD and aerosol radiative forcing in the future period with a contribution of $45 \%$. Finally, these various changes, similar for the different scenarios, lead to a total aerosol radiative forcing decrease between 1.2 and $2 \mathrm{~W} \mathrm{~m}^{-2}$. This work thus highlights the need for climate models to take nitrate particles into account, particularly for future climate studies over the Euro-Mediterranean region.

In addition, the study of the sensitivity of the future EuroMediterranean climate to anthropogenic aerosols highlights the important role of such particles on shortwave radiation but also shows that they have a more moderate impact on the future temperature over this region. Indeed, this work indicates that the anthropogenic aerosol evolution could explain about $65 \%$ of the yearly shortwave radiation change between past and future periods, but this could also explain about $6 \%$, or even $20 \%$ locally, of the expected yearly warming over Europe by mid-century for the SSP 5-8.5. This work therefore highlights that taking into account the aerosol evolution is essential for understanding the Euro-Mediterranean future climate trends. Finally, this work also illustrates that the presence of strong regional contrasts in terms of anthropogenic aerosol impact on surface temperature can be explained by the different (direct, indirect or semi-direct) aerosol radiative forcings.

These results show that the use of a regional climate modelling tool coupled with an interactive (natural and anthropogenic) aerosol scheme is adapted to investigate the complex anthropogenic particle feedbacks on the Euro-Mediterranean climate. Nevertheless, some assumptions such as the use of a time-constant nitric acid climatology need to be taken into account. Indeed, some studies, such as that of Cholakian et al. (2019) predict a nitrate precursor emissions decrease in the future, which would consequently have an effect on the evolution and the climatic impact of such particles. For this reason, the implementation of a time-dependent nitric acid climatology is envisaged in 


\section{First indirect effect}

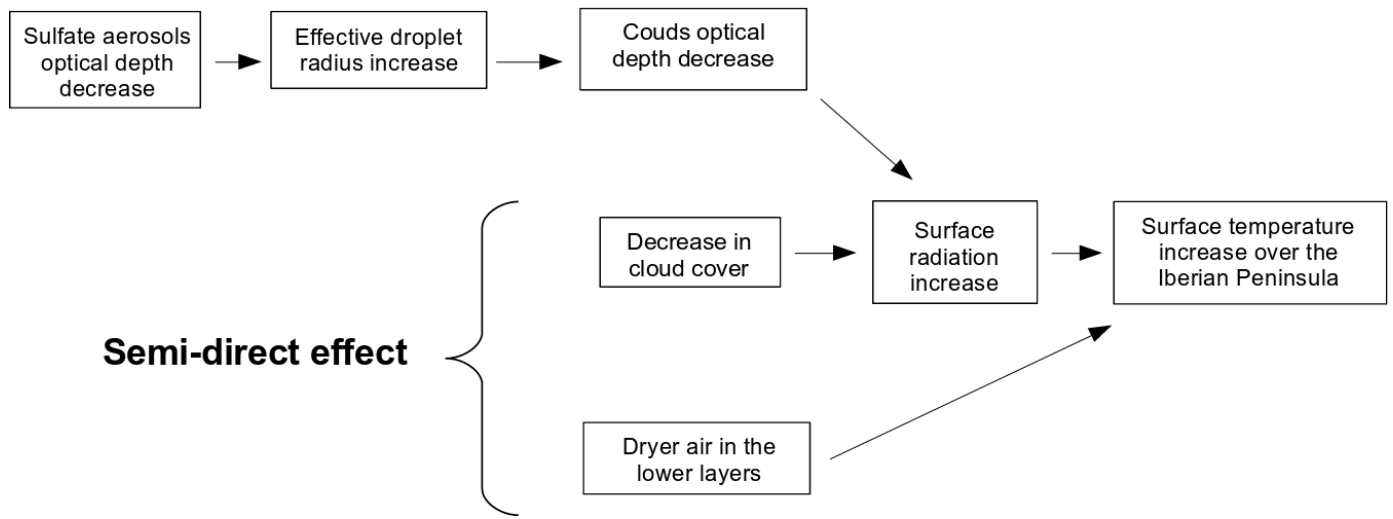

Figure 17. Summary of the anthropogenic aerosol role on the projected surface temperature increase over the Iberian Peninsula in summer between the periods 1971-2000 and 2021-2050.

a future version of the TACTIC aerosol scheme. Similarly, a better description of the indirect radiative forcing of nitrate aerosols in the CNRM-ALADIN63 model would allow a better estimation of the climatic impact of such anthropogenic particles. Besides, it is worth mentioning that the second indirect aerosol effect is not included in the present study and is still affected by large uncertainties in regional climate modelling. 


\section{Appendix A}
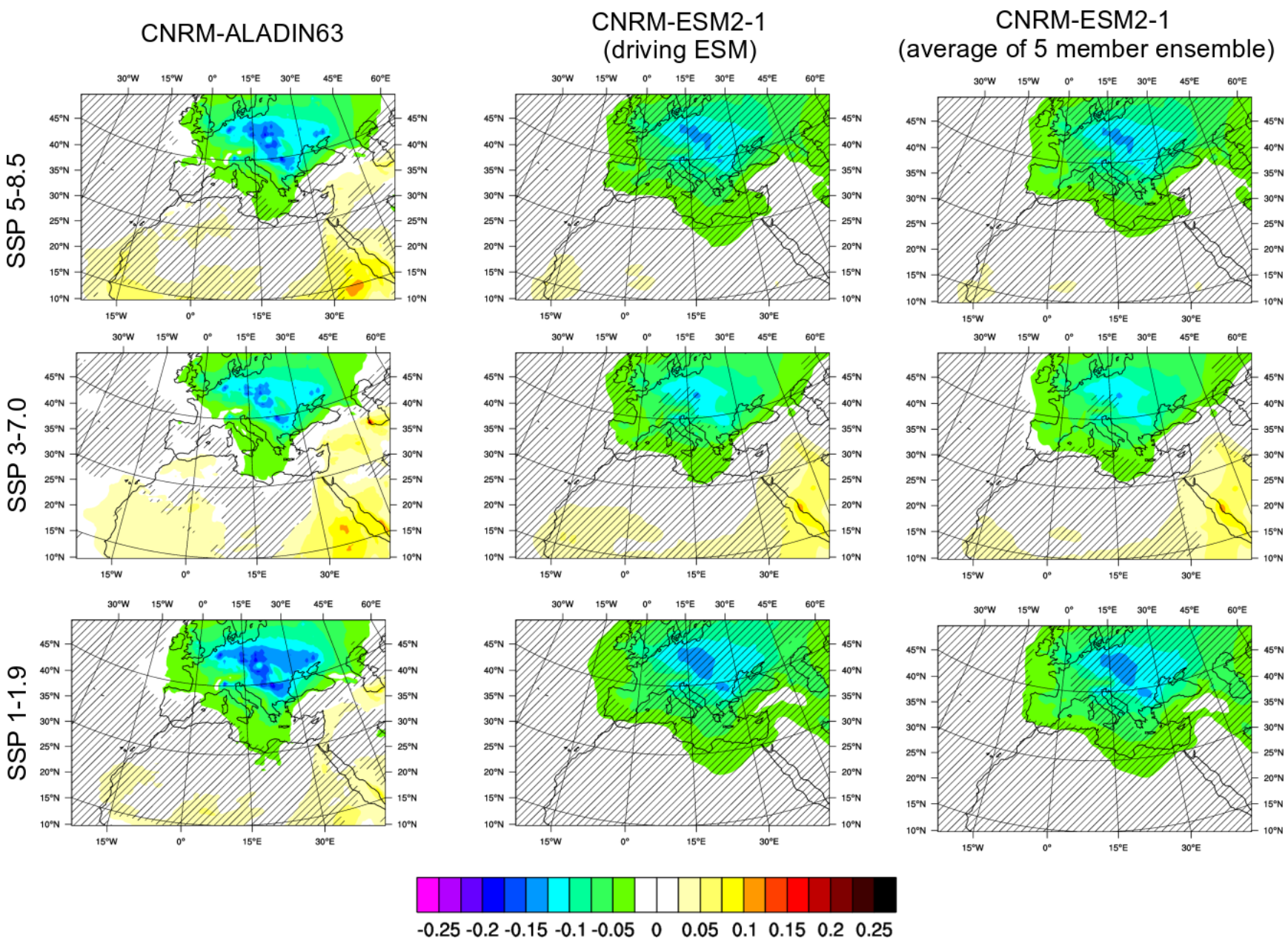

Figure A1. Total AOD evolution between the past period (1971-2000) and the future period (2021-2050) with the CNRM-ALADIN63 model and its driving ESM. The hatched areas are statically non-significant with a threshold of $10 \%$. 

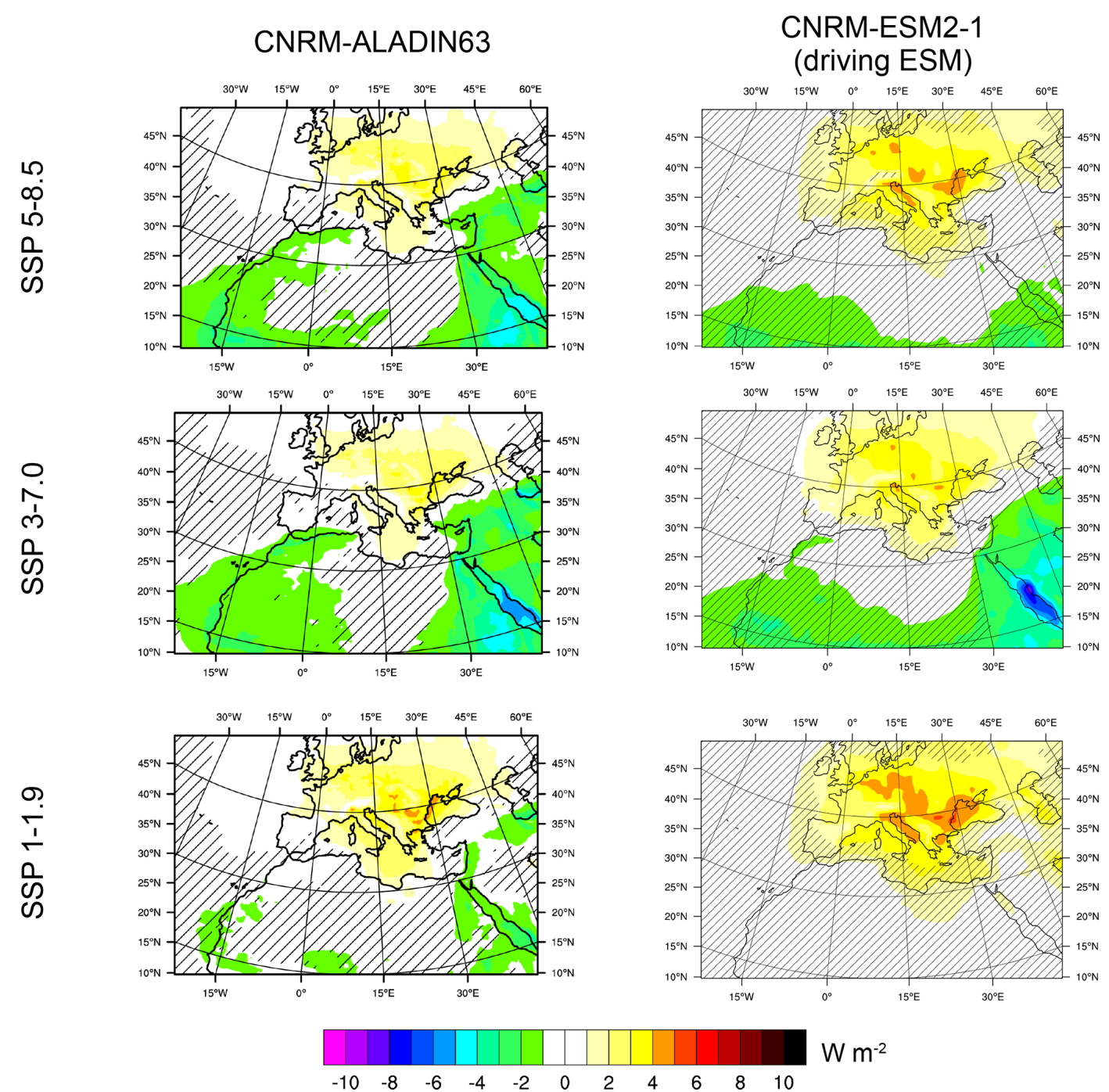

Figure A2. Surface SW DRF evolution between the past period (1971-2000) and the future period (2021-2050) with the CNRM-ALADIN63 model and its driving ESM. The hatched areas are statically non-significant with a threshold of $10 \%$. 

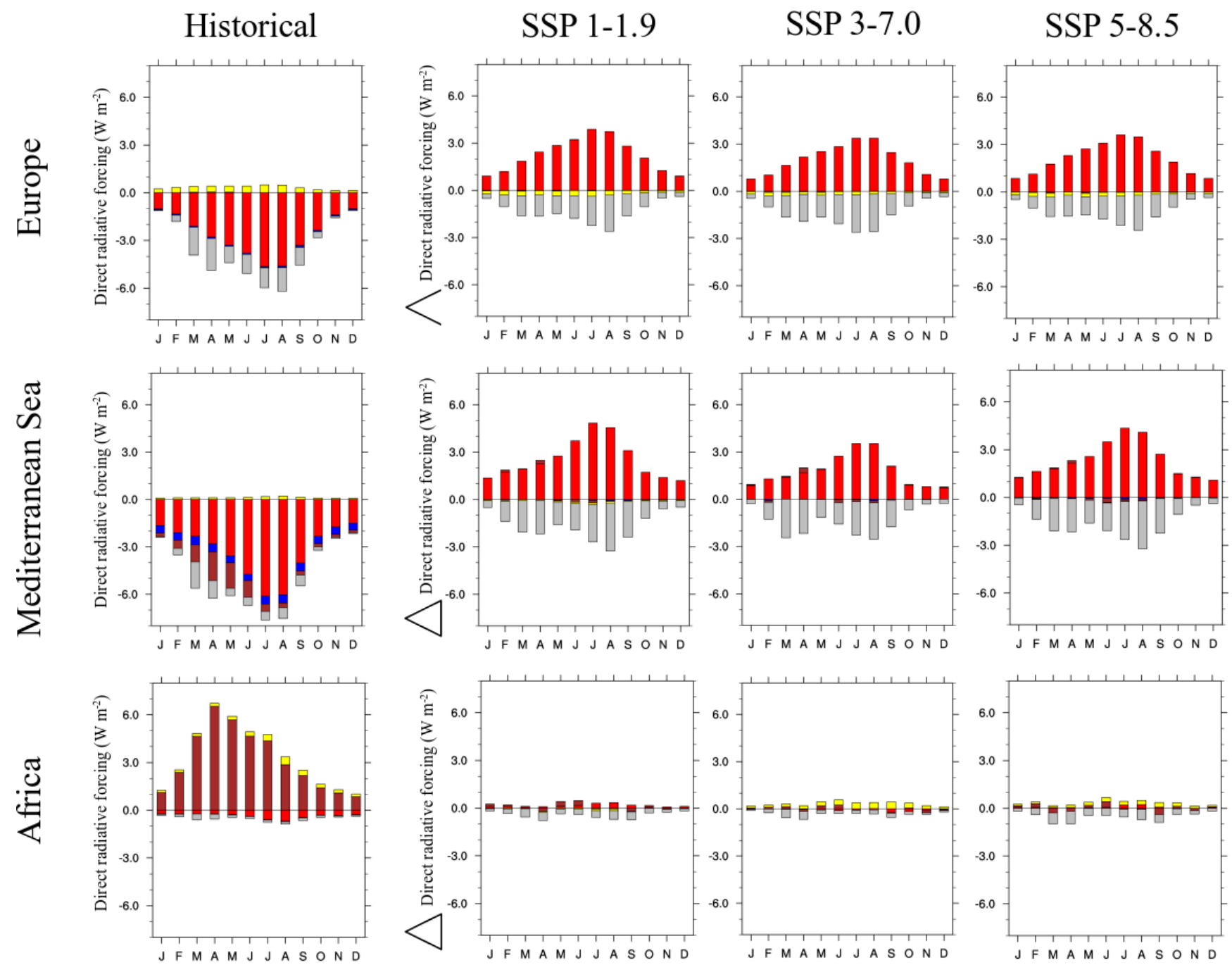

Sulfate and organic carbon

Sea salt

Dust

Black carbon

Nitrate and ammonium

Figure A3. SW DRF evolution $\left(\mathrm{W} \mathrm{m}^{-2}\right.$ ) at the TOA of sulfate and organic carbon (in red), sea salt (in blue), dust (in brown), black carbon (in yellow) and nitrate and ammonium (in grey) between the historical period (1971-2000) and the future period (2021-2050) according to SSPs 1-1.9, 3-7.0 and 5-8.5. 


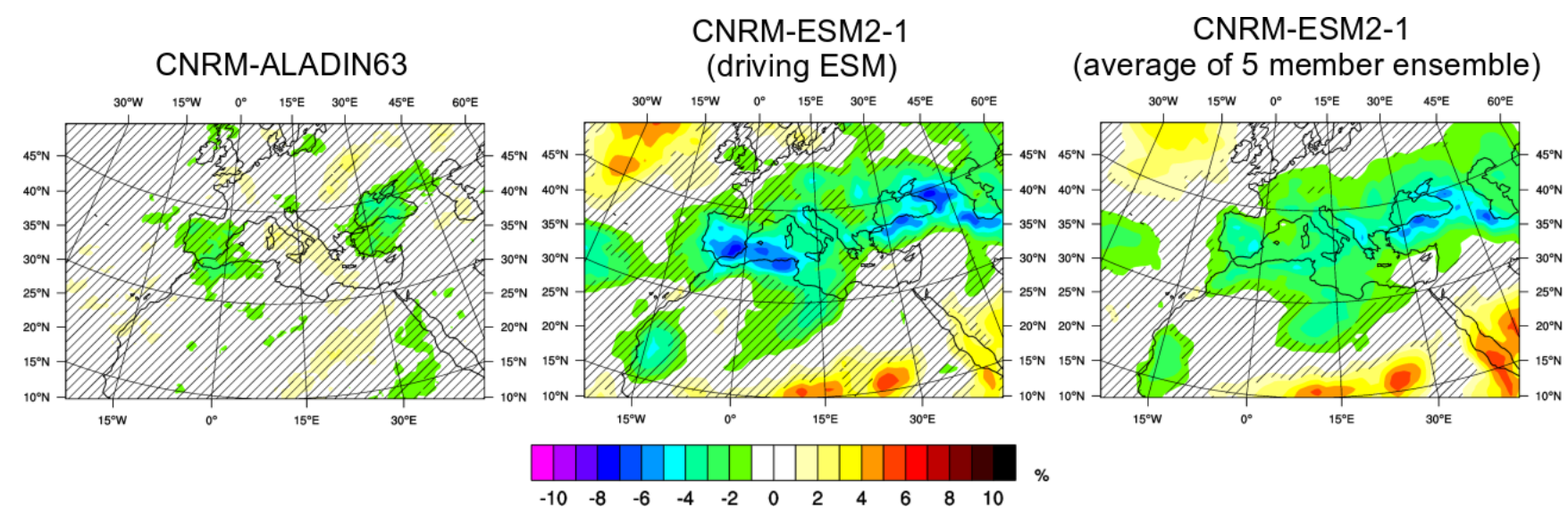

Figure A4. Mean difference for the months of June, July and August between SSP585 and SSP585cst simulations over the period 2021-2050 for cloud cover $(\%)$ with the CNRM-ALADIN63 model and its driving ESM. The hatched areas are statically non-significant with a threshold of $10 \%$. 
Code and data availability. The code of the regional climate model CNRM-ALADIN63 is available as follows: the SURFEX code is accessible using a CECILL-C licence (http://www.cecill.info/ licences/Licence_CeCILL-C_V1-en.txt, last access: 17 May 2021) at http://www.umr-cnrm.fr/surfex (last access: 17 May 2021), OASIS3-MCT is available at https://verc.enes.org/oasis/download (last access: 17 May 2021), XIOS at https://forge.ipsl.jussieu.fr/ ioserver (last access: 17 May 2021) and the rest of the CNRMALADIN63 code is available upon request from the authors. The output of the different simulations presented here are available upon request from the authors (thomas.druge@meteo.fr).

Author contributions. All authors designed the simulations and TD carried them out. TD prepared the manuscript with contributions from all co-authors.

Competing interests. The authors declare that they have no conflict of interest.

Special issue statement. This article is part of the special issue "CHemistry and AeRosols Mediterranean EXperiments (ChArMEx) (ACP/AMT inter-journal SI)”. It does not belong to a conference.

Acknowledgements. We would like to thank Météo-France and the Occitania region for the financial support of the first author. This work is part of the Med-CORDEX initiative (https://www. medcordex.eu/, last access: 9 October 2020) and a contribution to the CORDEX Flagship Pilot Study (FPS) on aerosols. It also provides a contribution to the ChArMEx programme, part of the French multidisciplinary programme MISTRALS (Mediterranean Integrated Studies aT Regional And Local Scales).

Review statement. This paper was edited by Xavier Querol and reviewed by two anonymous referees.

\section{References}

Ackerman, T. P. and Toon, O. B.: Absorption of visible radiation in atmosphere containing mixtures of absorbing and nonabsorbing particles, Appl. Opt., 20, 3661-3668, https://doi.org/10.1364/AO.20.003661, 1981.

Adams, P. J., Seinfeld, J. H., Koch, D., Mickley, L., and Jacob, D.: General circulation model assessment of direct radiative forcing by the sulfate-nitrate-ammonium-water inorganic aerosol system, J. Geophys. Res.-Atmos., 106, 1097-1111, https://doi.org/10.1029/2000JD900512, 2001.

Albrecht, B.: Aerosols, cloud microphysics, and fractional cloudiness, Science, 245, 1227-1230, https://doi.org/10.1126/science.245.4923.1227, 1989.
Allen, R. and Sherwood, S.: Aerosol-cloud semi-direct effect and land-sea temperature contrast in a GCM, Geophys. Res. Lett., 37, L07702, https://doi.org/10.1029/2010GL042759, 2010.

Allen, R. J., Turnock, S., Nabat, P., Neubauer, D., Lohmann, U., Olivié, D., Oshima, N., Michou, M., Wu, T., Zhang, J., Takemura, T., Schulz, M., Tsigaridis, K., Bauer, S. E., Emmons, L., Horowitz, L., Naik, V., van Noije, T., Bergman, T., Lamarque, J.F., Zanis, P., Tegen, I., Westervelt, D. M., Le Sager, P., Good, P., Shim, S., O'Connor, F., Akritidis, D., Georgoulias, A. K., Deushi, M., Sentman, L. T., John, J. G., Fujimori, S., and Collins, W. J.: Climate and air quality impacts due to mitigation of nonmethane near-term climate forcers, Atmos. Chem. Phys., 20, 9641-9663, https://doi.org/10.5194/acp-20-9641-2020, 2020.

Aumont, O. and Bopp, L.: Globalizing results from ocean in situ iron fertilization studies, Global Biogeo. Cy., 20, https://doi.org/10.1029/2005GB002591, 2006.

Basart, S., Pérez, C., Cuevas, E., Baldasano, J. M., and Gobbi, G. P.: Aerosol characterization in Northern Africa, Northeastern Atlantic, Mediterranean Basin and Middle East from direct-sun AERONET observations, Atmos. Chem. Phys., 9, 8265-8282, https://doi.org/10.5194/acp-9-8265-2009, 2009.

Bauer, S. E., Koch, D., Unger, N., Metzger, S. M., Shindell, D. T., and Streets, D. G.: Nitrate aerosols today and in 2030: a global simulation including aerosols and tropospheric ozone, Atmos. Chem. Phys., 7, 5043-5059, https://doi.org/10.5194/acp-7-50432007, 2007.

Bellouin, N., Rae, J., Jones, A., Johnson, C., Haywood, J., and Boucher, O.: Aerosol forcing in the Climate Model Intercomparison Project (CMIP5) simulations by HadGEM2-ES and the role of ammonium nitrate, J. Geophys. Res.-Atmos., 116, D20206, https://doi.org/10.1029/2011JD016074, 2011.

Bellouin, N., Quaas, J., Gryspeerdt, E., Kinne, S., Stier, P., WatsonParris, D., Boucher, O., Carslaw, K. S., Christensen, M., Daniau, A.-L., Dufresne, J.-L., Feingold, G., Fiedler, S., Forster, P., Gettelman, A., Haywood, J. M., Lohmann, U., Malavelle, F., Mauritsen, T., McCoy, D. T., Myhre, G., Mülmenstädt, J., Neubauer, D., Possner, A., Rugenstein, M., Sato, Y., Schulz, M., Schwartz, S. E., Sourdeval, O., Storelvmo, T., Toll, V., Winker, D., and Stevens, B.: Bounding Global Aerosol Radiative Forcing of Climate Change, Rev. Geophys., 58, e2019RG000660, https://doi.org/10.1029/2019RG000660, 2020.

Benas, N., Hatzianastassiou, N., Matsoukas, C., Fotiadi, A., Mihalopoulos, N., and Vardavas, I.: Aerosol shortwave direct radiative effect and forcing based on MODIS Level 2 data in the Eastern Mediterranean (Crete), in: Advances in Meteorology, Climatology and Atmospheric Physics, Springer, 917-922, https://doi.org/10.1007/978-3-642-29172-2_128, 2013.

Boé, J., Somot, S., Corre, L., and Nabat, P.: Large discrepancies in summer climate change over Europe as projected by global and regional climate models: causes and consequences, Clim. Dynam., 54, 2981-3002, https://doi.org/10.1007/s00382020-05153-1, 2020.

Boucher, O., Randall, D., Artaxo, P., Bretherton, C., Feingold, G., Forster, P., Kerminen, V.-M., Kondo, Y., Liao, H., Lohmann, U., Rasch, P., Satheesh, S. K., Sherwood, S., Stevens, B., and Zhang, X. Y.: Clouds and aerosols, in: Climate change 2013: the physical science basis, Contribution of Working Group I to the Fifth Assessment Report of the Intergovernmental Panel on Climate Change, Cambridge University Press, 571-657, 2013. 
Cholakian, A., Colette, A., Coll, I., Ciarelli, G., and Beekmann, M.: Future climatic drivers and their effect on $\mathrm{PM}_{10}$ components in Europe and the Mediterranean Sea, Atmos. Chem. Phys., 19, 4459-4484, https://doi.org/10.5194/acp-19-4459-2019, 2019.

Coakley Jr., J. A., Cess, R. D., and Yurevich, F. B.: The effect of tropospheric aerosols on the Earth's radiation budget: A parameterization for climate models, J. Atmos. Sci., 40, 116-138, https://doi.org/10.1175/15200469(1983)040<0116:TEOTAO>2.0.CO;2, 1983.

Coppola, E., Nogherotto, R., Ciarlo', J. M., Giorgi, F., van Meijgaard, E., Kadygrov, N., Iles, C., Corre, L., Sandstad, M., Somot, S., Nabat, P., Vautard, R., Levavasseur, G., Schwingshackl, C., Sillmann, J., Kjellström, E., Nikulin, G., Aalbers, E., Lenderink, G., Christensen, O. B., Boberg, F., Sørland, S. L., Demory, M.-E., Bülow, K., Teichmann, C., Warrach-Sagi, K., and Wulfmeyer, V.: Assessment of the European climate projections as simulated by the large EURO-CORDEX regional and global climate model ensemble, J. Geophys. Res.-Atmos., 126, e2019JD032356, https://doi.org/10.1029/2019JD032344, 2021.

Da Silva, N., Mailler, S., and Drobinski, P.: Aerosol indirect effects on summer precipitation in a regional climate model for the Euro-Mediterranean region, Ann. Geophys., 36, 321-335, https://doi.org/10.5194/angeo-36-321-2018, 2018.

Decharme, B., Delire, C., Minvielle, M., Colin, J., Vergnes, J.-P., Alias, A., Saint-Martin, D., Séférian, R., Sénési, S., and Voldoire, A.: Recent Changes in the ISBA-CTRIP Land Surface System for Use in the CNRM-CM6 Climate Model and in Global OffLine Hydrological Applications, J. Adv. Model. Earth Sy., 11, 1207-1252, https://doi.org/10.1029/2018MS001545, 2019.

Dentener, F., Kinne, S., Bond, T., Boucher, O., Cofala, J., Generoso, S., Ginoux, P., Gong, S., Hoelzemann, J. J., Ito, A., Marelli, L., Penner, J. E., Putaud, J.-P., Textor, C., Schulz, M., van der Werf, G. R., and Wilson, J.: Emissions of primary aerosol and precursor gases in the years 2000 and 1750 prescribed data-sets for AeroCom, Atmos. Chem. Phys., 6, 43214344, https://doi.org/10.5194/acp-6-4321-2006, 2006.

Drugé, T., Nabat, P., Mallet, M., and Somot, S.: Model simulation of ammonium and nitrate aerosols distribution in the Euro-Mediterranean region and their radiative and climatic effects over 1979-2016, Atmos. Chem. Phys., 19, 3707-3731, https://doi.org/10.5194/acp-19-3707-2019, 2019.

Eyring, V., Bony, S., Meehl, G. A., Senior, C. A., Stevens, B., Stouffer, R. J., and Taylor, K. E.: Overview of the Coupled Model Intercomparison Project Phase 6 (CMIP6) experimental design and organization, Geosci. Model Dev., 9, 1937-1958, https://doi.org/10.5194/gmd-9-1937-2016, 2016.

Forster, P., Ramaswamy, V., Artaxo, P., Berntsen, T., Betts, R., Fahey, D., Haywood, J., Lean, J., Lowe, D., Myhre, G., Nganga, J., Prinn, R., Raga, G., Schulz, M., and Van Dorland, R.: Changes in Atmospheric Constituents and in Radiative Forcing, in: Climate Change 2007: The Physical Science Basis. Contribution of Working Group I to the Fourth Assessment Report of the Intergovernmental Panel on Climate Change, edited by: Solomon, S., Qin, D., Manning, M., Chen, Z., Marquis, M., Averyt, K. B., Tignor, M., and Miller, H. L., 129-234, 2007.

Forster, P. M., Richardson, T., Maycock, A. C., Smith, C. J., Samset, B. H., Myhre, G., Andrews, T., Pincus, R., and Schulz, M.: Recommendations for diagnosing effective radiative forcing from climate models for CMIP6, J. Geophys. Res.-Atmos., 121, 12460, https://doi.org/10.1002/2016JD025320, 2016.

Fouquart, Y. and Bonnel, B.: Computations of solar heating of the earth's atmosphere- A new parameterization, Beitraege zur Physik der Atmosphaere, 53, 35-62, 1980.

Gao, X., Pal, J. S., and Giorgi, F.: Projected changes in mean and extreme precipitation over the Mediterranean region from a high resolution double nested RCM simulation, Geophys. Res. Lett., 33, L03706, https://doi.org/10.1029/2005GL024954, 2006.

Georgoulias, A. K., Alexandri, G., Kourtidis, K. A., Lelieveld, J., Zanis, P., Pöschl, U., Levy, R., Amiridis, V., Marinou, E., and Tsikerdekis, A.: Spatiotemporal variability and contribution of different aerosol types to the aerosol optical depth over the Eastern Mediterranean, Atmos. Chem. Phys., 16, 13853-13884, https://doi.org/10.5194/acp-16-13853-2016, 2016.

Ghan, S. J.: Technical Note: Estimating aerosol effects on cloud radiative forcing, Atmos. Chem. Phys., 13, 9971-9974, https://doi.org/10.5194/acp-13-9971-2013, 2013.

Gibelin, A.-L. and Déqué, M.: Anthropogenic climate change over the Mediterranean region simulated by a global variable resolution model, Clim. Dynam., 20, 327-339, https://doi.org/10.1007/s00382-002-0277-1, 2003.

Gidden, M. J., Riahi, K., Smith, S. J., Fujimori, S., Luderer, G., Kriegler, E., van Vuuren, D. P., van den Berg, M., Feng, L., Klein, D., Calvin, K., Doelman, J. C., Frank, S., Fricko, O., Harmsen, M., Hasegawa, T., Havlik, P., Hilaire, J., Hoesly, R., Horing, J., Popp, A., Stehfest, E., and Takahashi, K.: Global emissions pathways under different socioeconomic scenarios for use in CMIP6: a dataset of harmonized emissions trajectories through the end of the century, Geosci. Model Dev., 12, 14431475, https://doi.org/10.5194/gmd-12-1443-2019, 2019.

Giorgi, F.: Climate change hot-spots, Geophys. Res. Lett., 33, L08707, https://doi.org/10.1029/2006GL025734, 2006.

Giorgi, F. and Lionello, P.: Climate change projections for the Mediterranean region, Glob. Planet. Change, 63, 90-104, https://doi.org/10.1016/j.gloplacha.2007.09.005, 2008.

Gutiérrez, C., Somot, S., Nabat, P., Mallet, M., Corre, L., van Meijgaard, E., Perpiñán, O., and Gaertner, M. Á.: Future evolution of surface solar radiation and photovoltaic potential in Europe: investigating the role of aerosols, Environ. Res. Lett., 15, 034035, https://doi.org/10.1088/1748-9326/ab6666, 2020.

Hansen, J., Sato, M., and Ruedy, R.: Radiative forcing and climate response, J. Geophys. Res.-Atmos., 102, 6831-6864, https://doi.org/10.1029/96JD03436, 1997.

Hauglustaine, D. A., Balkanski, Y., and Schulz, M.: A global model simulation of present and future nitrate aerosols and their direct radiative forcing of climate, Atmos. Chem. Phys., 14, 1103111063, https://doi.org/10.5194/acp-14-11031-2014, 2014.

Herrmann, M., Somot, S., Calmanti, S., Dubois, C., and Sevault, F.: Representation of spatial and temporal variability of daily wind speed and of intense wind events over the Mediterranean Sea using dynamical downscaling: impact of the regional climate model configuration, Nat. Hazards Earth Syst. Sci., 11, 19832001, https://doi.org/10.5194/nhess-11-1983-2011, 2011.

Hewitt, C. D.: Ensembles-based predictions of climate changes and their impacts, Eos T. Am. Geophys. Union, 85, 566-566, https://doi.org/10.1029/2004EO520005, 2004.

Hoesly, R. M., Smith, S. J., Feng, L., Klimont, Z., JanssensMaenhout, G., Pitkanen, T., Seibert, J. J., Vu, L., Andres, R. 
J., Bolt, R. M., Bond, T. C., Dawidowski, L., Kholod, N., Kurokawa, J.-I., Li, M., Liu, L., Lu, Z., Moura, M. C. P., O'Rourke, P. R., and Zhang, Q.: Historical (1750-2014) anthropogenic emissions of reactive gases and aerosols from the Community Emissions Data System (CEDS), Geosci. Model Dev., 11, 369-408, https://doi.org/10.5194/gmd-11-369-2018, 2018.

Inness, A., Ades, M., Agustí-Panareda, A., Barré, J., Benedictow, A., Blechschmidt, A.-M., Dominguez, J. J., Engelen, R., Eskes, H., Flemming, J., Huijnen, V., Jones, L., Kipling, Z., Massart, S., Parrington, M., Peuch, V.-H., Razinger, M., Remy, S., Schulz, M., and Suttie, M.: The CAMS reanalysis of atmospheric composition, Atmos. Chem. Phys., 19, 3515-3556, https://doi.org/10.5194/acp-19-3515-2019, 2019.

IPCC: Climate change 2013: the physical science basis: Working Group I contribution to the Fifth assessment report of the Intergovernmental Panel on Climate Change, Cambridge University Press, Cambridge, 2013.

Jacob, D., Petersen, J., Eggert, B., Alias, A., Christensen, O. B., Bouwer, L. M., Braun, A., Colette, A., Déqué, M., Georgievski, G., Georgopoulou, E., Gobiet, A., Menut, L., Nikulin, G., Haensler, A., Hempelmann, N., Jones, C., Keuler, K., Kovats, S., Kröner, N., Kotlarski, S., Kriegsmann, A., Martin, E., van Meijgaard, E., Moseley, C., Pfeifer, S., Preuschmann, S., Radermacher, C., Radtke, K., Rechid, D.,Rounsevell, M., Samuelsson, P., Somot, S., Soussana, J.-F., Teichmann, C., Valentini, R., Vautard, R., Weber, B., and Yiou, P.: EUROCORDEX: new high-resolution climate change projections for European impact research, Reg. Environ. Change, 14, 563-578, https://doi.org/10.1007/s10113-013-0499-2, 2014.

Jacobson, M. Z.: Global direct radiative forcing due to multicomponent anthropogenic and natural aerosols, J. Geophys. Res.-Atmos., 106, 1551-1568, https://doi.org/10.1029/2000JD900514, 2001.

Lacressonnière, G., Peuch, V.-H., Vautard, R., Arteta, J., Déqué, M., Joly, M., Josse, B., Marécal, V., and Saint-Martin, D.: European air quality in the 2030s and 2050s: impacts of global and regional emission trends and of climate change, Atmos. Environ., 92, 348-358, https://doi.org/10.1016/j.atmosenv.2014.04.033, 2014.

Lacressonnière, G., Watson, L., Gauss, M., Engardt, M., Andersson, C., Beekmann, M., Colette, A., Foret, G., Josse, B., Marécal, V., Nyiri, A., Siour, G., Sobolowski, S., and Vautard, R.: Particulate matter air pollution in Europe in a+ 2 C warming world, Atmos. Environ., 154, 129-140, https://doi.org/10.1016/j.atmosenv.2017.01.037, 2017.

Le Moigne, P., Colin, J., and Decharme, B.: Impact of lake surface temperatures simulated by the Flake scheme in the CNRM-CM5 climate model, Tellus A, 68, 31274, https://doi.org/10.3402/tellusa.v68.31274, 2016.

Lefevre, F., Brasseur, G., Folkins, I., Smith, A., and Simon, P.: Chemistry of the 1991-1992 stratospheric winter: Threedimensional model simulations, J. Geophys. Res.-Atmos., 99, 8183-8195, https://doi.org/10.1029/93JD03476, 1994.

Lelieveld, J., Berresheim, H., Borrmann, S., Crutzen, P., Dentener, F., Fischer, H., Feichter, J., Flatau, P., Heland, J., Holzinger, R., Korrmann, R., Lawrence, M. G., Levin, Z., Markowicz, K. M., Mihalopoulos, N., Minikin, A., Ramanathan, V., de Reus, M., Roelofs, G. J., Scheeren, H. A., Sciare, J., Schlager, H., Schultz, M., Siegmund, P., Steil, B., Stephanou, E. G., Stier, P., Traub, M., Warneke, C., Williams, J., and Ziereis, H.: Global air pollu- tion crossroads over the Mediterranean, Science, 298, 794-799, https://doi.org/10.1126/science.1075457, 2002.

Liao, H. and Seinfeld, J. H.: Global impacts of gas-phase chemistryaerosol interactions on direct radiative forcing by anthropogenic aerosols and ozone, J. Geophys. Res.-Atmos., 110, D18208, https://doi.org/10.1029/2005JD005907, 2005.

Lohmann, U. and Feichter, J.: Global indirect aerosol effects: a review, Atmos. Chem. Phys., 5, 715-737, https://doi.org/10.5194/acp-5-715-2005, 2005.

Madec, G., Bourdallé-Badie, R., Chanut, J., Clementi, E., Coward, A., Ethé, C., Iovino, D., Lea, D., Lévy, C., Lovato, T., Martin, N., Masson, S., Mocavero, S., Rousset, C., Storkey, D., Vancoppenolle, M., Müeller, S., Nurser, G., Bell, M., and Samson, G.: NEMO ocean engine, Notes du Pôle de modélisation de l'Institut Pierre-Simon Laplace (IPSL), Zenodo, https://doi.org/10.5281/zenodo.1472492, 2017.

Markakis, K., Valari, M., Colette, A., Sanchez, O., Perrussel, O., Honore, C., Vautard, R., Klimont, Z., and Rao, S.: Air quality in the mid-21st century for the city of Paris under two climate scenarios; from the regional to local scale, Atmos. Chem. Phys., 14, 7323-7340, https://doi.org/10.5194/acp-14-7323-2014, 2014.

Masson, V., Le Moigne, P., Martin, E., Faroux, S., Alias, A., Alkama, R., Belamari, S., Barbu, A., Boone, A., Bouyssel, F., Brousseau, P., Brun, E., Calvet, J.-C., Carrer, D., Decharme, B., Delire, C., Donier, S., Essaouini, K., Gibelin, A.-L., Giordani, H., Habets, F., Jidane, M., Kerdraon, G., Kourzeneva, E., Lafaysse, M., Lafont, S., Lebeaupin Brossier, C., Lemonsu, A., Mahfouf, J.-F., Marguinaud, P., Mokhtari, M., Morin, S., Pigeon, G., Salgado, R., Seity, Y., Taillefer, F., Tanguy, G., Tulet, P., Vincendon, B., Vionnet, V., and Voldoire, A.: The SURFEXv7.2 land and ocean surface platform for coupled or offline simulation of earth surface variables and fluxes, Geosci. Model Dev., 6, 929-960, https://doi.org/10.5194/gmd-6-929-2013, 2013.

Matthes, K., Funke, B., Andersson, M. E., Barnard, L., Beer, J., Charbonneau, P., Clilverd, M. A., Dudok de Wit, T., Haberreiter, M., Hendry, A., Jackman, C. H., Kretzschmar, M., Kruschke, T., Kunze, M., Langematz, U., Marsh, D. R., Maycock, A. C., Misios, S., Rodger, C. J., Scaife, A. A., Seppälä, A., Shangguan, M., Sinnhuber, M., Tourpali, K., Usoskin, I., van de Kamp, M., Verronen, P. T., and Versick, S.: Solar forcing for CMIP6 (v3.2), Geosci. Model Dev., 10, 2247-2302, https://doi.org/10.5194/gmd-10-2247-2017, 2017.

Meinshausen, M., Vogel, E., Nauels, A., Lorbacher, K., Meinshausen, N., Etheridge, D. M., Fraser, P. J., Montzka, S. A., Rayner, P. J., Trudinger, C. M., Krummel, P. B., Beyerle, U., Canadell, J. G., Daniel, J. S., Enting, I. G., Law, R. M., Lunder, C. R., O'Doherty, S., Prinn, R. G., Reimann, S., Rubino, M., Velders, G. J. M., Vollmer, M. K., Wang, R. H. J., and Weiss, R.: Historical greenhouse gas concentrations for climate modelling (CMIP6), Geosci. Model Dev., 10, 2057-2116, https://doi.org/10.5194/gmd-10-2057-2017, 2017.

Mélia, D. S.: A global coupled sea ice-ocean model, Ocean Model., 4, 137-172, https://doi.org/10.1016/S1463-5003(01)00015-4, 2002.

Michou, M., Nabat, P., and Saint-Martin, D.: Development and basic evaluation of a prognostic aerosol scheme (v1) in the CNRM Climate Model CNRM-CM6, Geosci. Model Dev., 8, 501-531, https://doi.org/10.5194/gmd-8-501-2015, 2015. 
Michou, M., Nabat, P., Saint-Martin, D., Bock, J., Decharme, B., Mallet, M., Roehrig, R., Séférian, R., Sénési, S., and Voldoire, A.: Present-day and historical aerosol and ozone characteristics in CNRM CMIP6 simulations, J. Adv. Model. Earth Sy., 12, e2019MS001816, https://doi.org/10.1029/2019MS001816, 2020.

Mitchell, J. M.: The effect of atmospheric aerosols on climate with special reference to temperature near the Earth's surface, J. Appl. Meteor., 10, 703-714, https://doi.org/10.1175/15200450(1971)010<0703:TEOAAO>2.0.CO;2, 1971.

Mlawer, E. J., Taubman, S. J., Brown, P. D., Iacono, M. J., and Clough, S. A.: Radiative transfer for inhomogeneous atmospheres: RRTM, a validated correlated- $k$ model for the longwave, J. Geophys. Res.-Atmos., 102, 16663-16682, https://doi.org/10.1029/97JD00237, 1997.

Morcrette, J., Barker, H., Cole, J., Iacono, M., and Pincus, R.: Impact of a new radiation package, McRad, in the ECMWF Integrated Forecasting System, Mon. Weather Rev., 136, 4773-4798, https://doi.org/10.1175/2008MWR2363.1, 2008.

Morcrette, J.-J., Boucher, O., Jones, L., Salmond, D., Bechtold, P., Beljaars, A., Benedetti, A., Bonet, A., Kaiser, J., Razinger, M., Schulz, M., Serrar, S., Simmons, A. J., Sofiev, M., Suttie, M., Tompkins, A. M., and Untch, A.: Aerosol analysis and forecast in the European Centre for medium-range weather forecasts integrated forecast system: Forward modeling, J. Geophys. Res.Atmos., 114, D06206, https://doi.org/10.1029/2008JD011235, 2009.

Myhre, G., Samset, B. H., Schulz, M., Balkanski, Y., Bauer, S., Berntsen, T. K., Bian, H., Bellouin, N., Chin, M., Diehl, T., Easter, R. C., Feichter, J., Ghan, S. J., Hauglustaine, D., Iversen, T., Kinne, S., Kirkevåg, A., Lamarque, J.-F., Lin, G., Liu, X., Lund, M. T., Luo, G., Ma, X., van Noije, T., Penner, J. E., Rasch, P. J., Ruiz, A., Seland, Ø., Skeie, R. B., Stier, P., Takemura, T., Tsigaridis, K., Wang, P., Wang, Z., Xu, L., Yu, H., Yu, F., Yoon, J.-H., Zhang, K., Zhang, H., and Zhou, C.: Radiative forcing of the direct aerosol effect from AeroCom Phase II simulations, Atmos. Chem. Phys., 13, 1853-1877, https://doi.org/10.5194/acp13-1853-2013, 2013a.

Myhre, G., Shindell, D., and Pongratz, J.: Anthropogenic and natural radiative forcing in: Climate change 2013: the physical science basis. Working Group I contribution to the fifth assessment report of the Intergovernmental Panel on Climate Change, Cambridge University Press, Cambridge, UK, New York, https://doi.org/10.1017/CBO9781107415324.018, 2013b.

Myhre, G., Samset, B. H., Mohr, C. W., Alterskjær, K., Balkanski, Y., Bellouin, N., Chin, M., Haywood, J., Hodnebrog, Ø., Kinne, S., Lin, G., Lund, M. T., Penner, J. E., Schulz, M., Schutgens, N., Skeie, R. B., Stier, P., Takemura, T., and Zhang, K.: Cloudy-sky contributions to the direct aerosol effect, Atmos. Chem. Phys., 20, 8855-8865, https://doi.org/10.5194/acp20-8855-2020, 2020.

Nabat, P., Solmon, F., Mallet, M., Kok, J. F., and Somot, S.: Dust emission size distribution impact on aerosol budget and radiative forcing over the Mediterranean region: a regional climate model approach, Atmos. Chem. Phys., 12, 10545-10567, https://doi.org/10.5194/acp-12-10545-2012, 2012.

Nabat, P., Somot, S., Mallet, M., Chiapello, I., Morcrette, J. J., Solmon, F., Szopa, S., Dulac, F., Collins, W., Ghan, S., Horowitz, L. W., Lamarque, J. F., Lee, Y. H., Naik, V., Nagashima, T., Shin- dell, D., and Skeie, R.: A 4-D climatology (1979-2009) of the monthly tropospheric aerosol optical depth distribution over the Mediterranean region from a comparative evaluation and blending of remote sensing and model products, Atmos. Meas. Tech., 6, 1287-1314, https://doi.org/10.5194/amt-6-1287-2013, 2013.

Nabat, P., Somot, Sand Mallet, M., Sanchez-Lorenzo, A., and Wild, M.: Contribution of anthropogenic sulfate aerosols to the changing Euro-Mediterranean climate since 1980, Geophys. Res. Lett., 41, 5605-5611, https://doi.org/10.1002/2014GL060798, 2014.

Nabat, P., Somot, S., Mallet, M., Sevault, F., Chiacchio, M., and Wild, M.: Direct and semi-direct aerosol radiative effect on the Mediterranean climate variability using a coupled regional climate system model, Clim. Dynam., 44, 1127-1155, https://doi.org/10.1007/s00382-014-2205-6, 2015.

Nabat, P., Somot, S., Cassou, C., Mallet, M., Michou, M., Bouniol, D., Decharme, B., Drugé, T., Roehrig, R., and SaintMartin, D.: Modulation of radiative aerosols effects by atmospheric circulation over the Euro-Mediterranean region, Atmos. Chem. Phys., 20, 8315-8349, https://doi.org/10.5194/acp-208315-2020, 2020.

Noilhan, J. and Planton, S.: A simple parameterization of land surface processes for meteorological models, Mon. Weather Rev., 117, 536-549, https://doi.org/10.1175/15200493(1989)117<0536:ASPOLS>2.0.CO;2, 1989.

Oki, T. and Sud, Y.: Design of Total Runoff Integrating Pathways (TRIP)—A global river channel network, Earth Interactions, 2, 1-37, https://doi.org/10.1175/10873562(1998)002<0001:DOTRIP>2.3.CO;2, 1998.

O’Neill, B. C., Kriegler, E., Ebi, K. L., Kemp-Benedict, E., Riahi, K., Rothman, D. S., van Ruijven, B. J., van Vuuren, D. P., Birkmann, J., Kok, K., Levy, M., and Solecki, W.: The roads ahead: Narratives for shared socioeconomic pathways describing world futures in the 21 st century, Glob. Environ. Change, 42, 169-180, https://doi.org/10.1016/j.gloenvcha.2015.01.004, 2017.

Papadimas, C. D., Hatzianastassiou, N., Matsoukas, C., Kanakidou, M., Mihalopoulos, N., and Vardavas, I.: The direct effect of aerosols on solar radiation over the broader Mediterranean basin, Atmos. Chem. Phys., 12, 7165-7185, https://doi.org/10.5194/acp-12-7165-2012, 2012.

Pavlidis, V., Katragkou, E., Prein, A., Georgoulias, A. K., Kartsios, S., Zanis, P., and Karacostas, T.: Investigating the sensitivity to resolving aerosol interactions in downscaling regional model experiments with WRFv3.8.1 over Europe, Geosci. Model Dev., 13 2511-2532, https://doi.org/10.5194/gmd-13-2511-2020, 2020.

Roehrig, R., Beau, I., Saint-Martin, D., Alias, A., Decharme, B., Guérémy, J.-F., Voldoire, A., Ahmat Younous, A.-L., Bazile, E., Belamari, S., Blein, S., Bouniol, D., Bouteloup, Y., Cattiaux, J., Chauvin, F., Chevallier, M., Colin, J., Douville, H., Marquet, P., Michou, M., Nabat, P., Oudar, T., Peyrillé, P., Piriou, J.-M., Salas y Mélia, D., Séférian, R., and Sénési, S.: The CNRM global atmosphere model ARPEGE-Climat 6.3: description and evaluation, J. Adv. Model. Earth Sy., 12, e2020MS002075, https://doi.org/10.1029/2020MS002075, 2020.

Ruti, P. M., Somot, S., Giorgi, F., Dubois, C., Flaounas, E., Obermann, A., Dell'Aquila, A., Pisacane, G., Harzallah, A., Lombardi, E., Ahrens, B., Akhtar, N., Alias, A., Arsouze, T., Aznar, R., Bastin, S., Bartholy, J., Béranger, K., Beuvier, J., Bouffies-Cloché, S., Brauch, J., Cabos, W., Calmanti, S., Calvet, J.-C., Carillo, A., Conte, D., Coppola, E., Djurdjevic, V., 
Drobinski, P., Elizalde-Arellano, A., Gaertner, M., Galàn, P., Gallardo, C., Gualdi, S., Goncalves, M., Jorba, O., Jordà, G., L'Heveder, B., Lebeaupin-Brossier, C., Li, L., Liguori, G., Lionello, P., Maciàs, D., Nabat, P., Önol, B., Raikovic, B., Ramage, K., Sevault, F., Sannino, G., Struglia, MV., Sanna, A., Torma, C., and Vervatis, V.: MED-CORDEX initiative for Mediterranean climate studies, B. Am. Meteorol. Soc., 97, 1187-1208, https://doi.org/10.1175/BAMS-D-14-00176.1, 2016.

Séférian, R., Nabat, P., Michou, M., Saint-Martin, D., Voldoire, A., Colin, J., Decharme, B., Delire, C., Berthet, S., Chevallier, M., Sénési, S., Franchisteguy, L., Vial, J., Mallet, M., Joetzjer, E., Geoffroy, O., Guérémy, J.-F., Moine, M.-P., Msadek, R., Ribes, A., Rocher, M., Roehrig, R., Salas-y-Mélia, D., Sanchez, E., Terray, L., Valcke, S., Waldman, R., Aumont, O., Bopp, L., Deshayes, J., Éthé, C., and Madec, G.: Evaluation of CNRM Earth System Model, CNRM-ESM2-1: Role of Earth System Processes in Present-Day and Future Climate, J. Adv. Model. Earth Sy., 11, 4182-4227, https://doi.org/10.1029/2019MS001791, 2019.

Shindell, D. T., Lamarque, J.-F., Schulz, M., Flanner, M., Jiao, C., Chin, M., Young, P. J., Lee, Y. H., Rotstayn, L., Mahowald, N., Milly, G., Faluvegi, G., Balkanski, Y., Collins, W. J., Conley, A. J., Dalsoren, S., Easter, R., Ghan, S., Horowitz, L., Liu, X., Myhre, G., Nagashima, T., Naik, V., Rumbold, S. T., Skeie, R., Sudo, K., Szopa, S., Takemura, T., Voulgarakis, A., Yoon, J.-H., and Lo, F.: Radiative forcing in the ACCMIP historical and future climate simulations, Atmos. Chem. Phys., 13, 2939-2974, https://doi.org/10.5194/acp-13-2939-2013, 2013.

Smith, C. J., Kramer, R. J., Myhre, G., Alterskjær, K., Collins, W., Sima, A., Boucher, O., Dufresne, J.-L., Nabat, P., Michou, M., Yukimoto, S., Cole, J., Paynter, D., Shiogama, H., O'Connor, F. M., Robertson, E., Wiltshire, A., Andrews, T., Hannay, C., Miller, R., Nazarenko, L., Kirkevåg, A., Olivié, D., Fiedler, S., Lewinschal, A., Mackallah, C., Dix, M., Pincus, R., and Forster, P. M.: Effective radiative forcing and adjustments in CMIP6 models, Atmos. Chem. Phys., 20, 9591-9618, https://doi.org/10.5194/acp-20-9591-2020, 2020.

Spyrou, C., Kallos, G., Mitsakou, C., Athanasiadis, P., Kalogeri, C., and Iacono, M. J.: Modeling the radiative effects of desert dust on weather and regional climate, Atmos. Chem. Phys., 13, 54895504, https://doi.org/10.5194/acp-13-5489-2013, 2013.

Stevens, B.: Rethinking the Lower Bound on Aerosol Radiative Forcing, J. Climate, 28, 4794-4819, https://doi.org/10.1175/JCLI-D-14-00656.1, 2015.

Tang, T., Shindell, D., Samset, B. H., Boucher, O., Forster, P. M., Hodnebrog, Ø., Myhre, G., Sillmann, J., Voulgarakis, A., Andrews, T., Faluvegi, G., Fläschner, D., Iversen, T., Kasoar, M., Kharin, V., Kirkevåg, A., Lamarque, J.-F., Olivié, D., Richardson, T., Stjern, C. W., and Takemura, T.: Dynamical response of Mediterranean precipitation to greenhouse gases and aerosols, Atmos. Chem. Phys., 18, 8439-8452, https://doi.org/10.5194/acp-18-8439-2018, 2018.
Thiébault, S. and Moatti, J.-P. (Eds.): The Mediterranean region under climate change : a scientific update, Synthèses, IRD; AllEnvi, available at: http://www.documentation.ird.fr/hor/fdi:010068463 (last access: 17 May 2021), 2016.

Thomason, L. W., Ernest, N., Millán, L., Rieger, L., Bourassa, A., Vernier, J.-P., Manney, G., Luo, B., Arfeuille, F., and Peter, T.: A global space-based stratospheric aerosol climatology: 1979-2016, Earth Syst. Sci. Data, 10, 469-492, https://doi.org/10.5194/essd-10-469-2018, 2018.

Twomey, S.: The influence of pollution on the shortwave albedo of clouds, J. Atmos. Sci. 34, 1149-1152, $\quad$ https://doi.org/10.1175/15200469(1977)034<1149:TIOPOT>2.0.CO;2, 1977.

van der Linden, P. and Mitchell, J.: ENSEMBLES: climate change and its impacts: summary of research and results from the ENSEMBLES project, Met Office Hadley Centre, Exeter, 2009.

van Marle, M. J. E., Kloster, S., Magi, B. I., Marlon, J. R., Daniau, A.-L., Field, R. D., Arneth, A., Forrest, M., Hantson, S., Kehrwald, N. M., Knorr, W., Lasslop, G., Li, F., Mangeon, S., Yue, C., Kaiser, J. W., and van der Werf, G. R.: Historic global biomass burning emissions for CMIP6 (BB4CMIP) based on merging satellite observations with proxies and fire models (1750-2015), Geosci. Model Dev., 10, 3329-3357, https://doi.org/10.5194/gmd-10-3329-2017, 2017.

Voldoire, A., Saint-Martin, D., Sénési, S., Decharme, B., Alias, A., Chevallier, M., Colin, J., Guérémy, J.-F., Michou, M., Moine, M.-P., Nabat, P., Roehrig, R., Salas y Mélia, D., Séférian, R., Valcke, S., Beau, I., Belamari, S., Berthet, S., Cassou, C., Cattiaux, J., Deshayes, J., Douville, H., Ethé, C., Franchistéguy, L., Geoffroy, O., Lévy, C., Madec, G., Meurdesoif, Y., Msadek, R., Ribes, A., Sanchez-Gomez, E., Terray, L., and Waldman, R.: Evaluation of CMIP6 DECK experiments with CNRM-CM6-1, J. Adv. Model. Earth Sy., 11, 2177-2213, https://doi.org/10.1029/2019MS001683, 2019.

Watson, L., Michou, M., Nabat, P., and Saint-Martin, D.: Assessment of CNRM coupled ocean-atmosphere model sensitivity to the representation of aerosols, Clim. Dynam., 51, 2877-2895, https://doi.org/10.1007/s00382-017-4054-6, 2018.

$\mathrm{Xu}$, L. and Penner, J. E.: Global simulations of nitrate and ammonium aerosols and their radiative effects, Atmos. Chem Phys., 12, 9479-9504, https://doi.org/10.5194/acp-12-94792012, 2012.

Zanis, P., Ntogras, C., Zakey, A., Pytharoulis, I., and Karacostas, T.: Regional climate feedback of anthropogenic aerosols over Europe using RegCM3, Clim. Res., 52, 267-278, https://doi.org/10.3354/cr01070, 2012.

Zubler, E., Folini, D., Lohmann, U., Lüthi, D., Muhlbauer, A., Pousse-Nottelmann, S., Schär, C., and Wild, M.: Implementation and evaluation of aerosol and cloud microphysics in a regional climate model, J. Geophys. Res.-Atmos., 116, D02211, https://doi.org/10.1029/2010JD014572, 2011. 